\title{
An alternative early opening scenario for the Central Atlantic Ocean
}

\author{
Cinthia Labails ${ }^{a, b, *}$, Jean-Louis Olivet ${ }^{a}$, Daniel Aslanian ${ }^{a}$, Walter R. Roest $^{a}$
}

a Ifremer Centre de Brest, DRO-Géosciences Marines, B.P. 70, 29280 Plouzané Cedex, France
b Center for Geodynamics, NGU-Geological Survey of Norway, Leiv. Eirikssons vei 39, N-7491 Trondheim,
Norway

*: Corresponding author : Cinthia Labails, Tel.: +47 73904467 ; fax: +47 73921620

email address : cinthia.labails@ngu.no

\begin{abstract}
:
The opening of the Central Atlantic Ocean basin that separated North America from northwest Africa is well documented and assumed to have started during the Late Jurassic. However, the early evolution and the initial breakup history of Pangaea are still debated: most of the existing models are based on one or multiple ridge jumps at the Middle Jurassic leaving the oldest crust on the American side, between the East Coast Magnetic Anomaly (ECMA) and the Blake Spur Magnetic Anomaly (BSMA). According to these hypotheses, the BSMA represents the limit of the initial basin and the footprint subsequent to the ridge jump. Consequently, the evolution of the northwest African margin is widely different from the northeast American margin. However, this setting is in contradiction with the existing observations. In this paper, we propose an alternative scenario for the continental breakup and the Mesozoic spreading history of the Central Atlantic Ocean. The new model is based on an analysis of geophysical data (including new seismic lines, an interpretation of the newly compiled magnetic data, and satellite derived gravimetry) and recently published results which demonstrate that the opening of the Central Atlantic Ocean started already during the Late Sinemurian (190 Ma), based on a new identification of the African conjugate to the ECMA and on the extent of salt provinces off Morocco and Nova Scotia. The identification of an African conjugate magnetic anomaly to BSMA, the African Blake Spur Magnetic Anomaly (ABSMA), together with the significant change in basement topography, are in good agreement with that initial reconstruction. The early opening history for the Central Atlantic Ocean is described in four distinct phases. During the first 20 Myr after the initial breakup (190$170 \mathrm{Ma}$, from Late Sinemurian to early Bajocian), oceanic accretion was extremely slow $(\sim 0.8 \mathrm{~cm} / \mathrm{y})$. At the time of Blake Spur (170 Ma, early Bajocian), a drastic change occurred both in the relative plate motion direction (from NNW-SSE to NW-SE) and in the spreading rate (an increase to $\sim 1.7 \mathrm{~cm} / \mathrm{y}$ ). After a small increase between Chron M25 ( $154 \mathrm{Ma}$, Kimmeridgian) and Chron M22 ( 150 Ma, Tithonian), the spreading rate slowed down to about $1.3 \mathrm{~cm} / \mathrm{y}$ and remained fairly constant until Chron M0 (125 Ma, Barremian-Aptian boundary). In addition, kinematic reconstructions illustrate a significant spreading asymmetry during the early history of the Central Atlantic Ocean; the accretion rates were higher on the American side and led to the formation of more oceanic crust on this plate. We infer that this asymmetry could be related to the fact that the thermal anomaly responsible for the significant magmatism of the Central Atlantic Magmatic Province (CAMP) was preferentially located below the African plate.
\end{abstract}

Keywords: Central Atlantic Ocean ; Mesozoic reversals ; Volcanism ; fracture zones ; spreading asymmetry ; reconstructions 


\section{Introduction}

The overall kinematic history of the Central Atlantic Ocean (CAO) is reasonably well documented and its history from Chron M0 onwards finely described (e.g. Müller and Roest, 1992). Here we consider the early seafloor spreading history across the Mid-Atlantic Ridge, between the Pico and Gloria fracture zones (FZ) in the north and the Fifteen-Twenty and Guinean FZ in the south (Figure 1). Although published kinematic models are able to reproduce some of the broad scale features of the tectonic history and the formation of the continental margins, a number of problems remain. In particular, they concern the initial fit and the timing of opening of the CAO, the early stages of seafloor spreading and the amount and timing of the independent motion of the Moroccan Meseta relative to the African plate.

More than four decades after the initial studies of the CAO kinematics, its early evolution is still debatable. Moreover, new studies on the Central Atlantic Magnetic Province (CAMP) magmatism (e.g. Nomade et al., 2007) raise questions on the volcanic nature of the Northeast American margin (NEAM) and its link with the East Coast Magnetic Anomaly (ECMA) and seaward dipping reflector sequences (SDRs) (Holbrook et al., 1994; Talwani et al., 1995). In addition, precise age dating poses the problem of the relationship between volcanism and breakup (e.g. Courtillot and Renne, 2003). The NEAM is characterized by a strong and continuous magnetic anomaly, the ECMA - considered as the continent ocean boundary - and a second magnetic anomaly, parallel and seaward to the ECMA, the Blake Spur Magnetic Anomaly (BSMA). Klitgord and Schouten (1986) proposed a fit which associates the ECMA and the BSMA, located on the Northwest African Margin (NWAM) at the time of the fit, and implies a spreading-center jump eastward to the BSMA. Their model has been successful because it explained the 
ridge jump proposed by Vogt (1973) and interpolated an age to the first accretion of oceanic crust at c. 175 Ma by incorporating the ridge jump at chron BSMA and a constant half spreading rate of $1.9 \mathrm{~cm} / \mathrm{y}$ between Chron M21 (147.7Ma) and the ECMA. Klitgord and Schouten's (1986) fit has served as the basis for many kinematics or stratigraphical works on the CAO (e.g. Roest et al., 1992; Withjack et al., 1998; Bird et al., 2007; Schettino and Turco, 2009). Nevertheless, the age of the onset of seafloor spreading remains controversial: Late Early Jurassic to early Middle Jurassic (185Ma to 175Ma) is an often adopted age, in particular for the northern part of the CAO, between Nova Scotia and Morocco (Withjack et al., 1998; Roeser et al., 2002; Schettino and Turco, 2009). Others workers (Wade and MacLean, 1990; Laville et al., 1995; Olsen, 1997; Le Roy and Piqué, 2001) proposed an age as late as Early Jurassic (195Ma to 185Ma). The onset of seafloor spreading is sometimes assumed to be diachronous with an initial opening at 200 Ma in the southern segment of the CAO, i.e. 15 Myrs older than the northern part. In 2004, Sahabi et al. proposed an initial fit which gives a coherent position of the ECMA relative to its African conjugate which they newly defined (West African Coast Magnetic Anomaly, WACMA) and considered the Central Atlantic synrift salt basins, now clearly constrained with deep seismic data, as key constraints in continental closure of the Central Atlantic margins. They estimated an age of Late Sinemurian (190Ma) for the first oceanic crust, on the base age of the salt deposits (Jansa et al., 1980; Wade and MacLean, 1990).

The present work proposes a kinematic model for the CAO from break-up until Chron M0 based on results of Sahabi et al. (2004) as well as on recent studies on the NWAM (Klingelhoefer et al., 2009; Labails et al., 2009). In the next sections, we describe first the method used for this study. It involves a comprehensive re-examination of magnetic lineations, fracture zones patterns and geological constraints. It integrates a gridded magnetic data-set with a recently compiled profile-based magnetic data-set off northwest Africa. The magnetic data-set used here is more extensive than those of the previous studies and provides better control for identifying the locations of magnetic lineations on opposite flanks, hence allowing a revision of the Mesozoic spreading history. We then discuss our alternative scenario for the early opening of the CAO, from Late Sinemurian (190 Ma) until Chron M0 (125 Ma, Barremian-Aptian boundary).

\section{Geophysical data}

The main geophysical data-sets used in this study are from publicly available magnetic and gravity sources. The gravity data are based on the satellite-derived free-air gravity anomaly grid (a one arc-minute grid of uniform coverage) over the CAO (Sandwell and Smith, 1997, V 9.1). 
The magnetic anomaly grid of Verhoef et al. (1996) covers the Arctic and North Atlantic oceans and adjacent land areas. While this data-set has provided a basis to better understand the early stages of the evolution of the CAO, a gridded dataset off northwest Africa (south of the Canary Islands) has been lacking. We have therefore compiled the digital magnetic data available over this region. This new compilation results mostly from a patchwork of regional surveys available from the National Geophysical Data Center GEOphysical Data System (GEODAS), from Ifremer and from others sources (van der Linden, 1981 and Roeser et al., 2002). All data were referenced to the International Geomagnetic Reference Field (IGRF10), spikes were removed manually, and finally the profiles were adjusted for cross-over errors using the micro-leveling method of Mauring and Kihle (2006). A more complete description of the magnetic data processing is provided in Appendix A.

On the western flank of the mid-Atlantic Ridge, in the area to the north of the Bahamas and south of $28^{\circ} \mathrm{N}$, magnetic anomaly picks were identified on ship track magnetic profiles from the GEODAS database.

All ages of magnetic anomalies referred to in this study are based on the time scale by Gradstein et al. (2004).

In addition, we also made used of geophysical data (multichannel seismics (MCS) and refraction) collected in two different portions of the NWAM that provide constraints on the deep architecture and nature of the margin. The first area concerns the margin and the deep salt province off Morocco (Contrucci et al. 2004, Sahabi et al., 2004). The second area is located off the Precambrian Reguibat Shield, a basement high between the Tarfaya-Laâyoune basin to the north and the Senegal basin to the south (Klingelhoefer et al., 2009; Labails et al., 2009).

\section{Data Analysis}

Figure 21 shows generalized boundaries of the seafloor spreading provinces on both sides of the CAO. Those located on the American side are particularly well known: the ECMA, a unique coastal magnetic anomaly, located near the continental shelf edge along the entire margin, a second noteworthy magnetic anomaly, the BSMA, and the M-series anomaly (M25 to M0). All have their counterparts on the NWAM as described below. 
In addition to geophysical criteria, the interpretation of geological features is crucial in plate kinematic reconstructions. In terms of kinematics, we face a three-plate problem: North America, northwest Africa and Morocco. The Moroccan Meseta is a large crustal block separated from the African craton during the formation of the Atlas Mountains by the reactivation of a major intracontinental rift system, at present inverted and deformed by the convergence of the African and European plates throughout Cenozoic times (Laville et al. 1977; Beauchamp et al., 1999 and references therein). The Atlas Mountains are typically divided into the High Atlas and Middle Atlas of Morocco and the Sahara Atlas of Algeria. The southern limit of the western High Atlas is represented by the Tizi n'Test Fault Zone (TTFZ) (Figure $\underline{3} z \mathrm{~b}$ ) which is assumed to have played a major role in the Late Paleozoic collision between North America and the African craton. The TTZF has been the site of dextral movements during this period followed by mainly sinistral strike-slip movements during the Trias-Early Jurassic rifting, and inversion and thrusting during Cretaceous and Tertiary (Proust et al., 1977; Laville et al., 1977; Frizon de Lamotte et al., 2000; Qarbous et al., 2003). All studies agree that horizontal movement does not exceed a few tens of kilometers (Proust et al. 1977; Laville et al., 1977; Beauchamp et al., 1999). Moreover, kinematics and paleomagnetic studies attested that this motion, during the Mesozoic, was small (Sichler et al., 1980; Olivet et al., 1984; Sahabi et al., 2004). Schettino and Turco (2009) estimate this movement to be much larger, based on changing fracture zone offsets. However, as explained in our detailed comment on their paper (Labails et al., submitted to GJI), their method of calculation is questionable, and the amount of motion thus derived (170 km of dextral offset) is not supported by data. The new model of the CAO proposed below does not imply a major motion of Morocco independent of northwest Africa before the Atlantic opening and through Jurassic time. Nevertheless, we claim that Morocco and northwest Africa have behaved as two distinct blocks from the end of the Paleozoic onwards.

Salt basins along the CAO margins are well developed (1000 km long) in the north, off Nova Scotia and Morocco. Salt deposits are also reported along the Carolina Trough on the NEAM, between $31.5^{\circ} \mathrm{N}$ and $35^{\circ} \mathrm{N}$, and between $16^{\circ} \mathrm{N}$ and $19^{\circ} \mathrm{N}$ off Senegal on the NWAM. New MCS data indicate local presence of salt in the Laâyoune basin (south of Canary Islands) that would extend the Moroccan salt basin as far south as $26^{\circ} \mathrm{N}$ (Davison and Dailly, 2010). In central parts of the CAO, there is no evidence of salt on the African margin (Sahabi et al., 2004; Labails et al., 2009). Davison and Taylor (2002) mentioned a small salt basin in the Baltimore Canyon Trough on the NEAM. Salt has also been described to the north of George Bank basin and Wade and Taylor (1990) assumed that it might represent a remnant, earlier connected to the Scotian basin and later isolated by the uplift on the Yarmouth Arch. Salt 
Surinam (Davison and Taylor, 2002). Even though most of them have been long known (e.g. Pautot et al., 1970), they had never been used to decipher the kinematics of continental closure because their extension was not well established. Sahabi et al. (2004), based on seismic interpretations, demonstrated that salt offshore Morocco extends $150 \mathrm{~km}$ seaward to the hinge line and corresponds to the outer limit of the $\mathrm{S}$ anomalies (Figure 2). On the conjugate margin, based on a seismic line published by Keen and Potter (1995), they interpreted the outflowing salt as a large post-rift, probably Late Jurassic, slide. Then, the ECMA coincides with the outermost limit of the salt basin. In fact, salt deposits in the CAO are commonly confined to individual basins. It is worthwhile noting that asymmetrical distribution of intracontinental rifted basins on both side of the CAO reflects the asymmetry of Hercynian-Alleghanian structures reactivated during the Triassic extension (Piqué and Laville, 1995). On the African side, these rifts occur only around the Moroccan Meseta whereas on Northeast America they extend from North Florida to the Grand Banks of Newfoundland. Their tectonic evolution led Whitjack et al. (1998) to propose a diachronous opening of the CAO: from south to north, the rift-drift transition occurred progressively later, from the Early Jurassic ( 200 Ma) to Middle Jurassic ( 185 Ma). Contrary to the American basins, the Atlasic basins, which mark the boundary between northwest Africa and Meseta, can be used as markers of plate motions of northwest Africa with respect to North America. They are connected to the Central Atlantic rift and witnessed the transition between evaporites and open-marine conditions deposits (Laville et al., 1995; Le Roy and Piqué, 2001) (see §4.1 and Figure 7).

\subsection{The Coastal Magnetic Anomalies: ECMA and WACMA}

The ECMA, discovered by Keller et al. (1954), is a positive magnetic anomaly of strong amplitude, reaching up to $350 \mathrm{nT}$, and is exceptionally continuous (Figure 4) over $2500 \mathrm{~km}$ along the margin. The southern part follows closely the edge of the continental shelf; further north it deviates to the east and south of Nova Scotia and is located hundreds of kilometers further offshore. To the South, the ECMA terminates east of Florida, where the anomaly bends towards the west, following Paleozoic structures (Brunswick anomaly). The ECMA closely mimics the lateral offsets of the hinge line (at $40^{\circ} \mathrm{N}$ and $42^{\circ} \mathrm{N}$ ), indicating its association with the passive margin, and it is thought to represent the continentocean boundary. However, the observed similarity in strike between the Appalachian structures and the magnetic lineation has often led to its interpretation as an Alleghanian suture during Late Paleozoic (McBride and Nelson, 1988; Matte, 2002). According to Sahabi et al. (2004), these points of view are not mutually exclusive. Seismic studies confirm the presence of typical oceanic crust beyond its seaward limit (Sheridan et al., 1982; Holbrook et al., 1994; Keen and Potter, 1995). Talwani et al. (1995) inferred a link between the ECMA and the seaward dipping reflector sequences (SDRs) observed during the EDGE 
experiment. Even where SDRs are not observed, these authors consider that the ECMA is due to excess volcanic material. The ECMA can be divided in three segments: south of $36^{\circ} \mathrm{N}$ and north of $41^{\circ} \mathrm{N}$, the anomaly shows a double peak, whereas it has a single peak in the central part. It is worth noting that this segmentation is also characterized by the presence of salt deposits in the Carolina Trough to the South, and in the Scotian Basin to the North of the Kelvin Seamounts .

The ECMA has its conjugate on the NWAM where it has weaker amplitude: the West Coast African Magnetic Anomaly (WACMA including S anomalies) as described by Sahabi et al. (2004) (Figure 2). North of $26^{\circ} \mathrm{N}$, studies of Verhoef et al. (1996) and Roeser et al. (2002) show, on both sides of the Canary Islands, an anomaly, S1, very similar to the ECMA in shape and position, with two major differences: a weaker amplitude and a continuation northward (anomaly S') not observed on the American side (Sahabi et al., 2004). Another anomaly, S3, follows partially the anomaly S1 between $29^{\circ} \mathrm{N}$ and $32^{\circ} \mathrm{N}$, giving it a comparable shape to the northern part of the ECMA. The $\mathrm{S}$ anomalies constitute a pair which seems to fade in the south towards $26.30^{\circ} \mathrm{N}$, off the Moroccan Sahara. South of that, a coastal anomaly similar to anomaly S was revealed by various authors (Rona et al., 1970; Hayes and Rabinowitz, 1975; Uchupi et al., 1976). Further south, Liger (1980) described and interpreted a rectilinear anomaly of more than $300 \mathrm{~km}$ long, the Senegal anomaly, comparable to the conjugate portion of the ECMA. Roussel and Liger (1983) and Olivet et al. (1984) considered that this anomaly represents the southern end of the S anomalies, as previously mentioned by Wissman and Roeser (1982). The same authors discussed the relationship between the seaward limit of salt provinces on the CAO margins and the coastal magnetic anomalies, and pointed out that the Senegal anomaly was located onshore with respect to the salt basin. More recently, Sahabi et al. (2004) described an offshore anomaly, between latitudes $15^{\circ} \mathrm{N}$ and $20^{\circ} \mathrm{N}$, parallel to the continental Senegal anomaly, and they infer that the combined onshore and offshore anomaly of Senegal form in fact the counterpart of the ECMA at this latitude, the WACMA. The location of both ECMA and WACMA straddles the salt basins. In this case, there is a striking symmetry between the Carolina Trough and the Senegal basin. In contrast to the American side, no SDRs have been clearly described on the NWAM, although Roeser et al. (2002) pointed out that anomaly S1 coincides with a poorly expressed SDRs sequence which is most likely its source. They also observed that seaward of anomaly S1 the structure of the basement may indicate excessive magma supply within the first $2 \mathrm{Myr}$ after breakup. On the Reguibat margin, the counterpart of the Baltimore Canyon Basin, Labails et al. (2009) showed that the WACMA is located underneath a rather thick continental crust ( 15 km); nevertheless its shape mimics the ECMA.

In summary, despite these differences, the ECMA and WACMA are two coastal magnetic anomalies with a trend and a location along the margin that are strikingly similar, as previously 
mentioned by Wissmann and Roeser (1982): "it is difficult to reject these anomalies which lie at the right place and have the right direction" .

\subsection{The Jurassic Magnetic Quiet Zone (JMQZ): the inner quiet magnetic zone and BSMA}

In the CAO, the JMQZ corresponds to a crust formed before Chron M25. On the American side, the only conspicuous magnetic lineation within the JMQZ is the BSMA (Taylor et al., 1968; Vogt et al., 1970; Vogt, 1973). Bird et al. (2007), in mapping similar lineations on the NWAM (as previously done by Roeser et al. (2002)) also attempted to identify M-series anomalies (M26 to M40) east of the BSMA. The Inner Magnetic Quiet Zone (IMQZ) (Rona et al., 1970, Rabinowitz et al., 1979) is defined between the ECMA and the BSMA. The BSMA is located 150 to $250 \mathrm{~km}$ seaward of the ECMA and is a loweramplitude and narrower magnetic anomaly than the ECMA but it has the same characteristic overall bent shape (Figure 3). From $35^{\circ} \mathrm{N}$ to $41^{\circ} \mathrm{N}$, it becomes barely identifiable. North of $41^{\circ} \mathrm{N}$, there is no clear equivalent anomaly. We observe weak linear magnetic anomalies oblique to ECMA (NNE-SSW) between $41^{\circ} \mathrm{N}$ and $44^{\circ} \mathrm{N}$, according to the magnetic map of Verhoef et al. (1996). The oldest crust dated in this region has been drilled $100 \mathrm{~km}$ east of the BSMA at DSDP 534 (Sheridan et al., 1982) which, by extrapolation, gave the age of the BSMA as c.170 Ma (early Bajocian). For many authors, the BSMA corresponds to an eastern ridge jump at c. 170 Ma leaving crust from both ridge flanks between the BSMA and the ECMA (e.g. Vogt et al., 1971; Vogt, 1973; Klitgord and Schouten, 1986; Withjack et al., 1998; Roest et al., 1992; Bird et al., 2007; Schettino and Turco, 2009). Nevertheless, the IMQZ does not show any evidence of a fossil ridge axis. Magnetic data shows a wide negative anomaly along the ECMA up to $43^{\circ} \mathrm{N}$, relayed seaward by a zone of low-amplitude anomalies (Figure $\underline{5} 4$ ). This transition coincides with a boundary between rough and smooth basement occurring at BSMA (Klitgord et al., 1988; Labails et al., 2009). For Grow and Markl (1977), and Markl and Bryan (1983), the rough-smooth basement boundary can be related to seafloor spreading rate changes (Sundvik et al., 1984). Slow spreading rates on today's active spreading axes are associated with rough topography (Macdonald, 1986; Small and Sandwell, 1989; Morgan and Ghen, 1993; Dick et al., 2003), and it is reasonable to assume that a similar relationship between spreading rate and basement roughness existed in the Mesozoic. However, Whittaker et al. (2008), based on global observations, consider that enhanced mantle temperatures during the early phase of opening are the primary cause of smooth seafloor.

Until the present study, it was not clear whether the BSMA and the IMQZ had a counterpart on the African plate. The magnetic field over the JMQZ off the northwest African margin is poorly known in comparison to that- on the northeast American side, and the amplitude of anomalies is generally weaker, with lineations therefore difficult to identify. The new magnetic grid (Appendix A) and the interpretation 
of individual magnetic profiles seaward of the WACMA allow us to recognize an anomaly located $~ 80$ $\mathrm{km}$ west of the anomaly S1 (Figures 1, 2 and 4). Its location along the NWAM is comparable with the BSMA: it is separated from the WACMA by the African conjugate of the IMQZ and is clearly expressed to the south of the Canary Islands. In addition, the interpretation of industrial seismic lines (Total, confidential data) allowed us to confirm a link between this anomaly and a change in basement topography (Figure 4 in Labails et al., 2009). Therefore, we consider that the BSMA does have a conjugate on the African plate and we name it the African Blake Spur Magnetic Anomaly (ABSMA). This revised interpretation is in a good agreement with the results of Sahabi et al. (2004) and has important implications for the earlier stage evolution of the CAO, as discussed later in this paper.

\subsection{Mesozoic reversals}

Magnetic anomalies produced by geomagnetic reversals that occurred during the seafloor spreading process are identified in a two-step process consisting of 1) simultaneous use of gridded data and profile magnetic anomalies to correlate significant anomaly trends, allowing identification of the seafloor spreading anomalies, and 2) correlation of the identified anomalies with model anomalies calculated from the geomagnetic timescale of Gradstein et al. (2004).

The M-series anomalies M0 to M25, which encompass 125-154 m.y. BP., are shown in figures 2b and 3b, together with the BSMA and ECMA and their conjugates. We have used the magnetic anomaly pickings of Klitgord and Schouten (1986) as our primary control for anomaly identifications and anomaly distances. In areas where profiles were available to us, we checked their identifications and added new ones where possible. This significantly increased the number of identifications, particularly south of the Canary Islands. Our identifications of various magnetic anomalies are generally the same as those of Klitgord and Schouten (1986). The main differences are a major shift of anomaly M25 and minor local shifts of anomalies M10n and M16. Over the American flank, north of $35.5^{\circ} \mathrm{N}$, our anomaly M25 identification is about 40 to $50 \mathrm{~km}$ further east. In the eastern Atlantic, our anomaly M25 is about $20 \mathrm{~km}$ to the west in the area north of $33^{\circ} \mathrm{N}$, while south of $24^{\circ} \mathrm{N}$ it is located about $50 \mathrm{~km}$ to the east. Other identification changes involve specific locations where our synthetic profiles enabled us to identify anomaly patterns. These changes in anomaly identification lead to changes in the calculated reconstructions poles.

Figure $\underline{6} 5$ illustrates the correlation of the identified anomalies with east-west oriented synthetic profiles from the gridded dataset at different latitudes and close to existing tracks (Verhoef et al., 1996 and our gridded data off northwest Africa). Two-dimensional magnetic models were generated using paleopole parameters for the remnant magnetic field (Besse and Courtillot, 2002) and a basement depth of 
$8 \mathrm{~km}$ for both northeast America and northwest Africa. North of the Kelvin Seamounts and the Canary Islands, the most spectacular feature remains the high amplitude of anomaly M0 which is related to a complex subaerial spreading axis, similar to that of Iceland, southeast of Grand Banks (e.g. Rabinowitz et al., 1979; Tulcholke and Ludwig, 1982). Globally, M-series anomaly groups on the NEAM are slightly wider on the NWAM; the asymmetry is obvious south of Kelvin Seamounts and Canary Islands.

\subsection{Fracture zones and flowlines}

We identified small- and medium-offset fracture zones from the gravity grid by picking the center of the gravity troughs corresponding to the deepest portion of the central fracture zone valleys (Figure 1). On Mesozoic crust, sediment fill has masked most troughs, which makes it more difficult to map the fracture zones this way. From north to south, the Pico-Gloria, Oceanographer, Atlantis, Kane, Jacksonville/Cape Verde and Fifteen-Twenty/Guinean FZ span the entire CAO, to distances up to 2000 $\mathrm{km}$ from the ridge axis, and most of them extend close to the continental margins, hence providing good constraints for the plate kinematic reconstructions. However, for the earliest stage, between closure and the Blake Spur magnetic anomaly, and with the exception of the Jacksonville/Cape Verde FZ, no reliable fracture zone directions have been observed.

\section{Kinematics of the Central Atlantic Ocean}

In the following, we present our alternative scenario for the early opening of the CAO, starting with the initial opening model of Sahabi et al. (2004), followed by the BSMA reconstruction and the fits of Chrons M25, M22 and M0 (Table 1). These stages reflect the main reorganizations in plate motions, with spreading rate and/or direction changes, and are displayed in Figure $\underline{7} 6$.

\subsection{Initial reconstruction}

Our kinematic model adopts the continental closure prior to breakup proposed by Sahabi et al. (2004) which highlights the fact that the age of the ECMA/WACMA, and thus the onset of seafloor spreading, needs to be re-evaluated. In their continental closure, the ECMA and the WACMA are juxtaposed and represent the continent-ocean boundaries. The Moroccan Meseta is slightly disconnected from the northwest African plate in order to improve the fit and to take into account the younger atlasic compression. Consequently large salt provinces off Nova Scotia and Morocco, as well as those of Carolina and Mauritania find themselves side by side. The presence of salt to the north and south of the 
CAO, bounded seaward by the continent-oceanic boundaries (ECMA/WACMA) suggests the presence of a unique salt basin connected to epicontinental seas of NW Europe through basins off Newfoundland and Portugal. Sahabi et al. (2004) consider that the new tectonic regime led to an acceleration of subsidence and then to a change in sedimentation deposits; they correlated the end of salt deposition with the onset of oceanic accretion. A consensus has existed for some time which considers Eurydice/Argo and Argana formations, on the NEAM and the NWAM respectively, as being synrift deposits, overlaid by the Iroquois/Mohican and Amstittene/Ameskhoud series, which themselves are considered as postrift series (Figure 7). On the Scotian basin, evaporites belong to the Argo formation and were dated by palynology as Rhaetian to Hettangian-Sinemurian (Jansa et al., 1980; Wade and MacLean, 1990 and reference therein). On the Moroccan margin, results of drillings (DSDP 544-547 of Leg 79; Hinz et al., 1982) give an age of Rhaetian-Hettangian to the evaporitic series. These evaporitic series are overlaid, locally unconformably, by the dolomitic Iroquois sequence in the Scotian basin, which are dated late Sinemurianearly Pliensbachian (Wade and McLean, 1990). On the Morocco margin, the evaporitic series are blanketed by the marine deposits (carbonates) dated as Hettangian-Pliensbachian (Le Roy and Piqué, 2001). The breakup episode is characterized by the transition in margin sedimentation from shallow-water deposits (evaporites) to open-water deposits (carbonates) and is then assumed to be synchronous with a minimum age of Late Sinemurian (190 Ma). Moreover, a recent study (Jourdan et al., 2009) indicates that CAMP volcanism took place over about fifteen Myr with two periods of peak activity at c. 203Ma and at c. 193 Ma. The CAMP event could thus be a trigger for breakup and initiation of seafloor spreading.

\subsection{Reconstruction at BSMA}

Figure 6b shows our reconstruction at Blake Spur time ( 170 Ma, early Bajocian), i.e. $20 \mathrm{Myr}$ after breakup. This was a time of major plate reorganization and a transition in margin sedimentation from Mohican/Ameskhoud formations (sandstones-shales) to Abenaki/Imouzzer formations (limestone) (Figure 7).

The configuration fits the BSMA-ABSMA and aligns the conjugate southernmost Jacksonville/Cap Vert fracture zones. At this time, about $5 \mathrm{~km}$ of sediments of the Mohican formation overlay the Argo formation (Wade and MacLean, 1990), indicating a rapid subsidence of the substratum of the salt provinces. In the northern part of the CAO, the position of Morocco is speculative because we do not have any obvious offshore constraints. The identification of magnetic lineations off Morocco (Figures $2 \mathrm{~b}$ and $3 \mathrm{~b}$ ) are too uncertain to define with accuracy an axis and to control the configuration. However, this approximate location is consistent with the kinematic evolution of the TTZF. 
To the South, the BSMA is juxtaposed with the Guinean plateau and we clearly observe that the oceanic domain created during the initial phase corresponds to the extent of the Blake Plateau. The Blake Plateau is commonly interpreted as a rifted-stage basement of about 10-20 km thickness (Dillon and Popenoe, 1998). We assume that it corresponds to an abnormal oceanic crust, such as for example the Iceland - Faroe ridge. The reorganization created a new spreading axis between the Blake Plateau and the Guinean Plateau. The presence of this anomaly should be linked to the Florida igneous province (De Boer et al., 1988) and a transform system complex between the CAO and the Gulf of Mexico (Klitgord and Schouten, 1986; Pindell and Kennan, 2009).

\subsection{Motions post-Blake Spur}

The evolution of the CAO post-BSMA is summarized by the series of sketches (Figure 6c-e), and the configuration of $\mathrm{CAO}$ through this time period is roughly comparable to the one proposed by previous models (Klitgord and Schouten, 1986; Bird et al., 2007). The Late Jurassic was characterized by stable plate motions but significant changes in spreading rates.

At Chron M-25, early Kimmeridgian (c. $154 \mathrm{Ma}$ ), our plate reconstruction shows a match of seafloor spreading anomalies and an alignment of the Jacksonville and Cape Verde fracture zones. This stage corresponds to a structural change in the basement observed on seismic lines between $22^{\circ} \mathrm{N}$ and $24^{\circ} \mathrm{N}$, off Dakhla. In fact, from the BSMA to the chron M25, the lower part of the crust is characterized by strong, oblique and discontinuous reflectors and a relatively smooth basement top. Seaward of chron M25, the crust resembles typical oceanic crust (Labails et al., 2009). In this area, chron M25 appears to be the time of a major tectonic event; however, due to a lack of data elsewhere, it is difficult to extend the interpretation of this regional event to that of a larger event at the scale of the CAO. In our reconstruction at chron M-22, Tithonian-Kimmeridgian boundary (c. $150 \mathrm{Ma}$ ), there is a match between SFSs data, fracture zones and flowlines, as well as a good alignment of the Kelvin Seamounts and the Canary Islands. Although the Canary Islands and the Kelvin Seamounts as observed today are a result of relatively recent tectonic and volcanic processes, their alignment suggests that their emplacement reactivated existing fracture zone directions (Olivet et al., 1984). A sharp decrease in spreading rate occurred at that time.

The end of the Lower Cretaceous, at the Barremian-Aptian boundary (Chron M0, c. $125 \mathrm{Ma}$ ), was an important stage in the development of the North Atlantic Ocean: the Iberian Peninsula moved eastward along Africa and the Bay of Biscay started to open. Europe and North America also began to separate (Olivet et al., 1984; Srivastava et al., 2000; Sibuet et al., 2004). In addition, Chron M0 marked the 
beginning of the Cretaceous quiet magnetic period, during which no magnetic reversals occurred. In our reconstruction, magnetic lineations fit well and the flowlines satisfactorily follow the fracture zones.

\section{Discussion}

One of the principal new elements presented in this study is the identification of the ABSMA, and the resulting major change in the predicted direction of initial opening of the CAO. Our paleoreconstructions for younger Mesozoic times differ only slightly from previous studies. These slight differences result from additional magnetic anomaly identification and the use of more modern fracture zone data. In this discussion, we focus on these differences, and hence on the initial opening episode, beginning with the new starting point presented by Sahabi et al. (2004) who dated the onset of seafloor spreading at $190 \mathrm{Ma}$. We will then discuss the implications of our proposed plate kinematic model.

\section{1 $\quad$ Atlantic spreading rates}

Average half-spreading rates were calculated for one geographic location in Northwest Africa $\left(22^{\circ} \mathrm{N}\right.$, $17^{\circ} \mathrm{W}$ ) using the geomagnetic times scales of Gradstein et al. (2004). They are reported in a graph together with those of previous models (Klitgord and Schouten, 1986; Bird et al., 2007; Schettino and Turco, 2009) (Figure 8). The difference in spreading rate between the two flanks is shown for our model, and for the model of Bird et al. (2007). During the first $20 \mathrm{Myr}$ (190-170 Ma), the initial spreading episode in the CAO was relatively slow with a spreading rate of $\sim 0.8 \mathrm{~cm} / \mathrm{yr}$. This is close to the Jurassic spreading rate (fit-M21) reported by Schettino and Turco (2009), but is about 4 times lower than the ones proposed by Bird et al. (2007) and Klitgord and Schouten (1986), who assumed a constant spreading rate of $2.1 \mathrm{~cm} / \mathrm{yr}$ from M40 to S1, and of $1.9 \mathrm{~cm} / \mathrm{yr}$ from M21 to S1. Bird et al. (2007) observed an asymmetry in spreading rate, being around $22 \%$ greater on the American side. They explained this asymmetry by two ridge jumps, one within the IMQZ at c. 170Ma and the other between c. 159 Ma and c. $164 \mathrm{Ma}$, which they linked with the opening of the Gulf of Mexico. Our model does not support this hypothesis. There is no evidence for a ridge jump in the IMQZ; instead, at Blake Spur time (c. $170 \mathrm{Ma}$ ), our reconstruction shows a significant change in both the relative plate motion direction (from NNW-SSE to NW-SE) and the spreading rate (increasing to $\sim 1.7 \mathrm{~cm} / \mathrm{y}$ ) which is related to a significant change in basement topography. At Chron M25 ( 154 Ma), the spreading rate increased to $2.8 \mathrm{~cm} / \mathrm{yr}$. At Chron M22 ( $150 \mathrm{Ma})$, the spreading rate slowed down to $1.3 \mathrm{~cm} / \mathrm{yr}$, and remained fairly constant until Chron M0 ( 125 Ma). 
It is worthwhile noting that the high spreading rate depicted between M25-M22 would reduce when using a different scale. Gee and Kent (2007) and He et al. (2008) point out that the model of Gradstein et al. (2004) introduces a shift of the M-sequence back to the end of the Jurassic. Torsvik et al. (2009) prefer for this reason the Aptian M series time scale of Channel et al. (1995) and Gradstein et al. (1994) for the earlier part, since this is critical for understanding the early opening history of the South Atlantic. The resulting difference in spreading rates is relatively minor (fit-BSMA: $0.6 \mathrm{~cm} / \mathrm{yr}$; BSMA-M25: $1.6 \mathrm{~cm} / \mathrm{yr}$; M25-M22: $2.2 \mathrm{~cm} / \mathrm{yr}$; M22-M0: $1.2 \mathrm{~cm} / \mathrm{yr}$ ).

\subsection{Asymmetry}

In the hypothesis of a ridge jump (Vogt, 1973) that served as the basis for many kinematics models, CAO margins and adjacent oceanic basins are considered to be formed at different times. In contrast, our model shows that margins and breakup in the CAO are directly comparable. However, manifestations of rifting, location of breakup, and initial evolution remain asymmetric (Figures 9 and 10). To explain this, we need to examine the initial structures and rifting processes prior to breakup. Figure 9 represents the maximum closure of the CAO at Late Triassic (Labails, 2007) and shows that south of Canary Islands, rift basins are mostly located on the American side, favoring existing zones of weakness related to the orogeny. Rifting clearly followed structures that had developed during the final collision between Gondwana and North America in Carboniferous-Permian time. The remarkable continuity of the ECMA and WACMA, representing the breakup zone, suggests that this zone followed a discontinuity caused by the Paleozoic collision. South of Canary Islands, it appears shifted towards the east with respect to the distribution of the alleghanian structures. The reactivation of the Appalachian and Hercynian structures and their breakup location was most likely favored by a thermal anomaly that was located preferentially under the African plate. A large asymmetry is found in the volcanic activity to either side of the rift zone (Figure 9). There is a lateral offset between crustal and mantle weakness zones: the crustal ones are on the Paleozoic orogen whereas mantle ones appear to be located under the Africa plate, according to volcanism repartition.

In addition, we observed that the overall shape of the ECMA and WACMA on the one hand, and the BSMA on the other are quite different, the latter representing one single bend with no major offsets. This change in shape of the ridge axis implies local asymmetries, either by asymmetric spreading or local ridge jumps (Wernicke and Tilke, 1989; Bird et al., 2007). However, we concur that the asymmetry is more fundamental and widespread, i.e. that it continues after the initial spreading history. Figure 10 shows the M0 reconstruction, but now placed in the framework of the M0-BSMA stage pole. In this representation, Mesozoic oceanic fracture zones are trending approximately east-west. The projection 
allows for a direct observation of spreading asymmetry between the two flanks of the mid-Atlantic Ridge. The initial opening phase is very asymmetric, with on average $56 \%$ of the accretion taking place on the North American plate. Between the BSMA and M22, the accretion remains asymmetric, with excess accretion on the American plate reduced to 54\%. Finally, between M22 and M0, spreading asymmetry still occurs south of the Kelvin Seamounts - Canary Islands, with $48 \%$ of accretion on the African plate. However, the amount of asymmetry is variable from segment to segment.

This prolonged spreading asymmetry is consistent along the entire ridge south of the Kelvin SeamountsCanary Islands lineament, which seems to favor the interpretation relating it to the thermal structure of the mantle rather than that relating it to ridge jump. It has long been recognized that the mantle under the African continent was anomalously hot at the time of breakup. The opening of the CAO was preceded by widespread volcanic activity, producing the CAMP, a large igneous province (LIP) (Figure 9). LIPs are mostly basaltic and characterize catastrophically rapid partial melting of the mantle at shallow depths. CAMP erupted at $200 \mathrm{Ma}$ into an active Triassic rift system and propagated as far as Canada and Brazil (Marzoli et al., 1999).

\subsection{Initial opening direction}

Although the overall direction of plate motions predicted by our model since the BSMA does not deviate significantly from previous works, the initial opening direction is very different. We do not have independent evidence for this seafloor spreading direction because no reliable structural lineations are observed in the oldest ocean floor. However, we consider that both the initial fit and the BSMA reconstructions are well constrained by the characteristic bends they display. Between the BSMA and Chron M0, the fracture zone traces show little or no change in spreading direction. Our flowlines between Chron M0 and BSMA reflect this uniform spreading history, hence providing additional confidence in our BSMA reconstruction. The end result is a drastically different initial opening direction, calculated between two well constrained reconstructions. Not only is the direction of opening different but the spreading rate also differs, and is significantly lower.

This oblique opening direction implies a transtensional regime in the area of the Newfoundland Transform margin, which forms the southern edge of the Grand Banks. The basins located in this area may provide evidence for this, but at present there is no independent evidence to corroborate such an early opening direction. 


\section{Conclusions}

We have presented a new Mesozoic spreading history of the CAO. Our alternative plate kinematic model is based on magnetic anomalies, fracture zones and onshore geological features. The main conclusions are as follows:

1. The new starting point for the history of the CAO (Sahabi et al., 2004) has a number of elements in its favor. Their continental fit provides a more coherent position of ECMA relative to its African conjugate and accounts for the presence of deep salt basins located off the Moroccan and Scotian margins, as well as those off Mauritania and the Carolina Trough. In this reconstruction the end of salt deposition marks the onset of seafloor spreading; hence, the first oceanic crust in the CAO is formed during the Late Sinemurian (190 Ma). Moreover, this age is in good agreement with the age of the volcanic activity (CAMP) on both sides of the Atlantic ocean (200 Ma, before the end of salt deposits).

2. The identification of the African conjugate of BSMA is based on all available magnetic data and on the similarity in shape of the equivalent magnetic anomalies. In contrast to Bird et al. (2007), who considered the S1 anomaly as the African conjugate of the BSMA, this newly interpreted anomaly, mapped $\sim 80 \mathrm{~km}$ west of the $\mathrm{S} 1$ anomaly, represents the conjugate of the BSMA in our interpretation. This modification has important consequences for the earliest stage of evolution of the CAO: it does not support a ridge jump and implies a revised reconstruction at BSMA. The CAO basin is then notably opened at that time.

3. The initial opening direction implies a significant oblique plate motion and a slower spreading rate, both of which differ considerably from previous studies.

4. During the initial breakup and the first $20 \mathrm{Myr}$ of seafloor spreading (190-170 Ma), oceanic accretion was extremely slow (0.8 cm/yr). At Blake Spur time (c. $170 \mathrm{Ma}$, early Bajocian), a huge change occurred both in relative plate motion directions (from NNW-SSE to NW-SE) and in spreading rate (increasing to $1.7 \mathrm{~cm} / \mathrm{yr}$ ). The BSMA is related to a major basement topographic change. After an increase (up to $2.7 \mathrm{~cm} / \mathrm{y}$ ) between Chron M25 ( 154 Ma, Kimmeridgian) and Chron M22 onwards (150 Ma, base Tithonian), the spreading rate slowed down to about $1.3 \mathrm{~cm} / \mathrm{yr}$ and remained fairly constant during the Early Cretaceous, until Chron M0 (125 Ma, Barremian-Aptian boundary).

5. Finally, our kinematic reconstruction at MO illustrates the general asymmetry of the CAO domain, with early accretion rates of the ridge being much higher to the west. This asymmetry persisted until Chron M0 in the southern part of the CAO, and resulted in 
514

\section{Acknowledgements}

significantly more oceanic crust created on the American plate compared to its African counterpart.

The GMT software package (Wessel \& Smith, 2004) and the PLACA software (Matias et al., 2005) were used to produce diagrams. This work was supported by a PhD stipend awarded to Cinthia Labails by Ifremer and Total. Cinthia Labails acknowledges the support of Ifremer and IUEM towards this work, and NGU for support while preparing this paper. We thank Mohamed Sahabi for his fruitful discussions during the realization of this work and Mikaël Evain for constructing a preliminary magnetic grid. Cinthia Labails acknowledges discussions with Trond Torsvik and Kevin Burke and is indebted to Robin Watson for his corrections to the language of Shakespeare. 
(Beauchamp et al., 1999; Besse and Courtillot, 2002; Bird et al., 2007; Channell et al., 1995; Contrucci et al., 2004; Courtillot and Renne, 2003; Davison and Dailly, 2010; Davison and Taylor, 2002; de Boer et al., 1988; Dick et al., 2003; Dillon and Popenoe, 1988; Frizon de Lamotte et al., 2000; Gee and Kent, 2007; Gradstein et al., 2004; Gradstein et al., 1994; Grow and Markl, 1977; Hayes and Rabinowitz, 1975; He et al., 2008; Holbrook et al., 1994; Keen and Potter, 1995; Keller et al., 1954; Klingelhoefer et al., 2009; Klitgord et al., 1988; Klitgord and Schouten, 1986; Labails et al., 2009; Labails et al., submitted; Laville et al., 1995; Laville et al., 1977; Le Roy and Piqué, 2001; Liger, 1980; Macdonald, 1986; Markl and Bryan, 1983; Marzoli et al., 1999; Matias et al., 2005; Matte, 2002; Mauring and Kihle, 2006; McBride and Nelson, 1988; Morgan and Ghen, 1993; Müller and Roest, 1992; Nomade et al., 2007; Olivet et al., 1984; Olsen, 1997; Pautot et al., 1970; Pindell and Kennan, 2009; Piqué and Laville, 1995; Proust et al., 1977; Qarbous et al., 2003; Rabinowitz et al., 1979; Roeser et al., 2002; Roest et al., 1992)(Cousminer and Steinkrauss, 1988; Funck et al., 2004; Hinz et al., 1982; Jansa et al., 1980; Jansa and Wiedmann, 1982; Jourdan et al., 2009; Labails, 2007; Lancelot, 1980; Le Roy et al., 1997; Rona et al., 1970; Roussel and Liger, 1983; Sahabi et al., 2004; Sandwell and Smith, 1997; Schettino and Turco, 2009; Sheridan et al., 1982; Sibuet et al., 2004; Sichler et al., 1980; Small and Sandwell, 1989; Srivastava et al., 2000; Sundvik et al., 1984; Talwani et al., 1995; Taylor et al., 1968; Torsvik et al., 2009; Tucholke and Ludwig, 1982; Uchupi et al., 1976; Van der Linden, 1981; Verhoef et al., 1996; Vogt, 1973; Vogt et al., 1970; Wade and MacLean, 1990; Welsink et al., 1989; Wernicke and Tilke, 1989; Wessel and Smith, 2004; Whittaker et al., 2008; Winterer and Hinz, 1984; Wissmann and Roeser, 1982; Withjack et al., 1998)

Beauchamp, W., Allmendinger, R. W., Barazangi, M., Demnati, A., El Alji, M., and Dahmani, M., 1999, Inversion tectonics and the evolution of the High Atlas Mountains, Morocco, based on a geological-geophysical transect: Tectonics, v. 18.

Besse, J., and Courtillot, V., 2002, Apparent and true polar wander and the geometry of the geomagnetic field over the last 200 Myr: Journal of Geophysical Research, v. 107, p. doi:10.1029/2000JB000050.

Bird, D. E., Hall, S. A., Burke, K., Casey, J. F., and Sawyer, D. S., 2007, Early central Atlantic Ocean seafloor spreading history: Geosphere, v. 3, p. 282-298.

Channell, J. E. T., Erba, E., Nakanishi, M., and Tamaki, K., 1995, Late Jurassic-Early Cretaceous time scales and oceanic magnetic anomaly block models, in Berggren, W. A., Kent Dennis, V., Aubry, M. P., and Hardenbol, J., eds., Geochronology, time scales and global stratigraphic correlation: United States, SEPM (Society for Sedimentary Geology) - Special Publication No. 54, p. 51-63.

Contrucci, I., Klingelhofer, F., Perrot, J., Bartolome, R., Gutscher, M. A., Sahabi, M., Malod, J., and Rehault, J. P., 2004, The crustal structure of the NW Moroccan continental margin from wide-angle and reflection seismic data: Geophysical Journal International, v. 159, p. 117128.

Courtillot, V., and Renne, P. R., 2003, On the ages of flood basalt events: Comptes Rendus Geosciences, v. 335, p. 113-140.

Cousminer, H. L., and Steinkrauss, W. E., 1988, Biostratigraphy of the Cost G-2 well (Georges Bank) : A record pf late Triassic synrift evaporite deposition ; Liassic doming and mid Jurassic to Miocene postrift marine sedimentation, in Manspeizer, W., ed., Triassic - Jurasic Rifting ; Continental Breakup and the origin of the Atlantic Ocean and Passive Margins, 22 (A): New York, Developments in Geotectonics ; Elsevier, p. 167-184.

Davison, I., and Dailly, P., 2010, Salt tectonics in the Cap Boujdour Area, Aaiun Basin, NW Africa: Marine and Petroleum Geology, v. 27, p. 435-441.

Davison, I., and Taylor, B., 2002, Correlations of the Central Atlantic Salt Basins and Implications for their Hydrocarbon Potential

PESGB-HGS: First Annual International Symposium: London, p. 30.

de Boer, J. Z., McHone, J. G., Puffer, J. H., Ragland, P. C., and Whittington, D., 1988, Mesozoic and Cenozoic magmatism, in Sheridan, R. E., and Grow, J. A., eds., The Geology of North America. The Atlantic Continental Margin., 1-2, U. S. Geological Society of America.

Dick, H. J. B., Lin, J., and Schouten, H., 2003, An ultraslow-spreading class of ocean ridge: Nature, v. 426, p. 405-412. 
Dillon, W. P., and Popenoe, P., 1988, The Blake Plateau Basin and Carolina Trough, in Sheridan, R. E., and Grow, J. A., eds., The Atlantic Continental Margin, V1-2, U.S. Geological Society of America, The Geology of North America, p. 291-328.

Frizon de Lamotte, D., Saint Bezar, B., Bracèe, R., and Mercier, E., 2000, The two main steps of the Atlas building and geodynamics of the western Mediterranean: Tectonics, v. 19, p. 740-761.

Funck, T., Jackson, H. R., Louden Keith, E., Dehler Sonya, A., and Wu, Y., 2004, Crustal structure of the northern Nova Scotia rifted continental margin (Eastern Canada): Journal of Geophysical Research.

Gee, J. S., and Kent, D. V., 2007, Source of oceanic magnetic anomalies and the geomagnetic polarity timescale, in Kono, M., ed., Treatrise on Geophysics, 5, Geomagnetism, Elsevier, p. 455-507.

Gradstein, F. M., Ogg, J. G., Smith, A. G., Bleeker, W., and Lourens, L. J., 2004, A new Geologic Time Scale, with special reference to Precambrian and Neogene: Episodes, v. 27, p. 83-100.

Gradstein, M. F., Agterberg, F. P., Ogg, J. G., Hardenbol, J., Van Veen, P., Thierry, J., and Huang, Z., 1994, A Mesozoic time scale: Journal of Geophysical Research, v. 99, p. 24051-24074.

Grow, J. A., and Markl, R. G., 1977, IPOD-USGS multichannel seismic reflection profile from Cape Hatteras to the Mid-Atlantic Ridge: Geology, v. 5, p. 625-630

Hayes, D. E., and Rabinowitz, P. D., 1975, Mesozoic magnetic lineations and the magnetic quiet zone off Northwest Africa: Earth and Planetary Science Letters, v. 28, p. 105-115.

He, H., Pan, Y., Tauxe, L., Qin, H., and Zhu, R., 2008, Toward age determination of the M0r (Barremian-Aptian boundary) of the Early Cretaceous: Physics of the Earth and Planetary Interiors, v. 169, p. 41-48.

Hinz, K., Winterer, E. L., Baumgartner, P. O., Bradshaw, M. J., Channel, J. E. T., Jaffrezo, M., Jansa, L. F., Leckie, R. M., Moore, J. N., Rullkotter, J., Schaftenaar, C., Steiger, T. H., Vuchev, V., and Weigand, G. E., 1982, Preliminary results from D.S.D.P. Leg 79 Seaward of the Mazagan plateau off central Morocco., in Von Rad, U., Hinz, K., Sarnthein, M., and Seibold, E., eds., Geology of the Northwest African continental margin, Springer-Verlag, p. 23-33.

Holbrook, W. S., Purdy, G. M., Sheridan, R. E., Glover, L., Talwani, M., Ewing, J., and Hutchinson, D. R., 1994, Seismic structure of the U.S. Mid-Atlantic continental margin: Journal of Geophysical Research, v. 99, p. 17871-17891.

Jansa, L. F., BujaK, J. P., and Williams, G. L., 1980, Upper Triassic salt deposits of the Western North Atlantic: Canadian Journal of Earth Sciences, v. 17, p. 547-558.

Jansa, L. F., and Wiedmann, J., 1982, Mesozoic-Cenozoic development of the Eastern North American and Northwest African continental margins : A comparaison, in Von Rad, U., Hinz, K., Sarnthein, M., and Seibold, E., eds., Geology of the Northwest African continental margin, Springer-Verlag, p. 215-269.

Jourdan, F., Marzoli, A., Bertrand, H., Cirilli, S., Tanner, L. H., Kontak, D. J., McHone, G., Renne, P. R., and Bellieni, G., 2009, 40Ar/39Ar ages of CAMP in North America: Implications for the Triassic-Jurassic boundary and the 40K decay constant bias: Lithos, v. 110, p. 167180.

Keen, C. E., and Potter, D. P., 1995, Formation and evolution of the Nova Scotian rifted margin : evidence from deep seismic reflection data: Tectonics, v. 14, p. 918-932.

Keller, F. J., Menschke, J. L., and Alldredge, L. R., 1954, Aeromagnetic surveys in the Aleutian, Marshall and Bermuda Islands: Transactions American Geophysical Union, v. 35, p. 558-572.

Klingelhoefer, F., Labails, C., Cosquer, E., Rouzo, S., Géli, L., Aslanian, D., Olivet, J.-L., Sahabi, M., Nouzé, H., and Unternehr, P., 2009, Deep crustal structure of the SW-Morrocan margin from wide-angle and reflection seismic data (The DAKHLA experiment): Tectonophysics, v. 468, p. 63-82.

Klitgord, K. D., Hutchinson, D. R., and Schouten, H., 1988, U.S. Atlantic Continental margin; Structural and tectonic framework, in Sheridan, R. E., and Grow, J. A., eds., The Atlantic Continental Margin ; U.S., I-2, U. S. Geological Society of America, p. 19-55.

Klitgord, K. D., and Schouten, H., 1986, Plate kinematics of the central Atlantic, in Vogt, P. R., and Tucholke, B. E., eds., The Western North Atlantic Region, $\mathrm{M}$

M, The Geological Society of America, p. 351-378.

Labails, C., 2007, La marge sud-marocaine et les premières phases d'ouverture de l'océan Atlantique Central, Université de Bretagne Occidentale, 2 vol., 135, p. http://tel.archives-ouvertes.fr/tel-00266944/fr/

Labails, C., Olivet, J. L., and the Dakhla Study Group, 2009, Crustal structure of the SW Moroccan margin from wide-angle and reflection seismic data (the Dakhla experiment); Part B, The tectonic heritage: Tectonophysics, v. 468, p. 83-97.

Labails, C., Roest, W., and Torsvik, T. H., submitted, Comments on "Breakup of Pangaea and plate kinematics of the central Atlantic and Atlas regions" By Schettino and Turco: Geophysical Journal International.

Lancelot, Y., 1980, Birth and evolution of the 'Atlantic Tethys' (central North Atlantic), Memoires du B.R.G.M.: France, Bureau de Recherches Geologiques et Minieres, (BRGM) : Paris, France, p. 215-223.

Laville, E., Charroud, A., Fedan, B., Charroud, M., and Piqué, A., 1995, Inversion négative et rifting atlasique: le bassin triasique de Kerrouchkne (Moyen Atlas, Maroc): Bulletin de la Societe Geologique de France, v. 116, p. 364-374. 
Laville, E., Lesage, J. L., and Seguret, M., 1977, Géométrie, cinématique (dynamique) de la tectonique atlasique sur le versant sud du Haut Atlas marocain. Aperçu sur les tectoniques hercyniennes et tardi-hercyniennes: Bulletin de la Société Géologique de France, v. 7, XIX, p. 527-539.

Le Roy, P., and Piqué, A., 2001, Triassic-Liassic Western Moroccan synrift basins in relation to the Central Atlantic opening: Marine Geology, v. 172, p. 359-381.

Le Roy, P., Piqué, A., Le Gall, B., Brahim, L. A., Morabet, A. M., and Demnati, A., 1997, The Triassic-Liassic basins of western Morocco and the diachronous intracontinental Central Atlantic rifting: Bulletin de la Société Géologique de France, v. 168, p. 637-648.

Liger, J. L., 1980, Structure profonde du bassin sénégalo-mauritanien ; interprétation des données gravimétriques et magnétiques: Unpub. Doctorat d'Etat thesis, Université Saint Jérôme, 160 p.

Macdonald, K. C., 1986, The crest of the Mid-Atlantic Ridge: Models for crustal generation processes and tectonics, in Vogt, P. R., and Tulchoke, B. E., eds., The western North Atlantic Region, M, The Geological Society of America, p. 51-68.

Markl, R. G., and Bryan, G. M., 1983, Stratigraphic evolution of Blake Outer Ridge: AAPG Bulletin, v. 67, p. 666-683.

Marzoli, A., Renne, P. R., Piccirillo, E. M., Ernesto, M., Bellieni, G., and De Min, A., 1999, Extensive 200-Million-Year-Old Continental Flood Basalts of the Central Atlantic Magmatic Province: Science, v. 284, p. 616-618.

Matias, L. M., Olivet, J. L., Aslanian, D., and Fidalgo, L., 2005, PLACA: a white box for plate reconstruction and best-fit pole determination: Computers and Geosciences, v. 31, p. 437-452.

Matte, P., 2002, Variscides between the Appalachians and the Urals ; Similarities and differences between Paleozoic subduction and collision belts, in Martinez Catalan, J. R., Hatcher, R. D. J., Arenas, R., and Diaz Garcia, F., eds., Variscan - Appalachian dynamics ; the building of the Late Paleozoic basement. Special Paper - Geological Society of America. 364, Geological Society of America, p. 239251.

Mauring, E., and Kihle, O., 2006, Leveling aerogeophysical data using a moving differential median filter: Geophysics, v. 71, p. L5-l11.

McBride, J. H., and Nelson, K. D., 1988, Integration of COCORP deep reflection and magnetic anomaly analysis in the southeastern United States ; implications for origin of the Brunswick and East Coast magnetic anomalies: Geological Society of America Bulletin, v. 100, p. 436-445.

Morgan, J. P., and Ghen, J., 1993, Dependence of ridge-axis morphology on magma supply and spreading rate: Nature, v. 364, p. 706-708.

Müller, R. D., and Roest, W. R., 1992, Fracture Zones in the North Atlantic From Combined Geosat and Seasat Data: Journal of Geophysical Research, v. 97, p. 3337-3350.

Nomade, S., Knight, K. B., Beutel, E., Renne, P. R., Verati, C., Feraud, G., Marzoli, A., Youbi, N., and Bertrand, H., 2007, Chronology of the Central Atlantic Magmatic Province; implications for the central Atlantic rifting processes and the Triassic-Jurassic biotic crisis.; Triassic-Jurassic boundary events; problems, progress, possibilities: Palaeogeography, Palaeoclimatology, Palaeoecology, v. 244, p. 326-344.

Olivet, J. L., Bonnin, J., Beuzart, P., and Auzende, J. M., 1984, Cinématique de l'Atlantique Nord et Central, 54: Plouzané, CNEXO, p. 108.

Olsen, P. E., 1997, Stratigraphic record of the early Mesozoic breakup of Pangea in the Laurasia-Gondwana rift system: Annual Review of Earth and Planetary Sciences, v. 25, p. 337-401.

Pautot, G., Auzende, J.-M., and Le Pichon, X., 1970, Continuous Deep Sea Salt Layer along North Atlantic Margins related to Early Phase of Rifting: Nature, v. 227, p. 351-354.

Pindell, J. L., and Kennan, L., 2009, Tectonic evolution of the Gulf of Mexico, Caribbean and northern South America in the mantle reference frame; an update, in Kennan, L., ed., Geological Society Special Publications, 328: United Kingdom, Geological Society of London : London, United Kingdom, p. 1-55.

Piqué, A., and Laville, E., 1995, L'ouverture initiale de l'Atlantique Central: Bulletin de la Société Géologique de France, v. 166, p. 725-738.

Proust, F., Petit, J. P., and Tapponnier, P., 1977, L'accident du Tizi n'Test et le rôle des décrochements dans la tectonique du Haut Atlas Occidental (Maroc): Bulletin de la Société Géologique de France, v. 7, XIX, p. 541-551.

Qarbous, A., Medina, F., and Hoepffner, C., 2003, The Tizi n'Test basin (High Atlas, Morocco) : Example of the evolution of an oblique segment in the central Atlantic Rift during the Triassic: Canadian Journal of Earth Sciences, v. 40, p. 949-964.

Rabinowitz, P. D., Cande, S. C., and Hayes, D. E., 1979, The J-anomaly in the central North Atlantic Ocean, in Kaneps, A., ed., Initial Reports of the Deep Sea Drilling Project, Leg 43, 43, U.S. Gouvernment Printing Office, p. 879-885.

Roeser, H. A., Steiner, C., Schreckenberger, B., and Block, M., 2002, Structural development of the Jurassic Magnetic Quiet Zone off Morocco and identification of Middle Jurassic magnetic lineations: Journal of Geophysical Research Solid Earth, v. 107, p. NIL_1-NIL_23.

Roest, W., Danobeitia, J. J., Verhoef, J., and Collette, B. J., 1992, Magnetic Anomalies in the Canary Basin and the Mesozoic Evolution of the Central North Atlantic: Marine Geophysical Researches, v. 14, p. 1-24.

Rona, P. A., Brakl, J., and Heirtzler, J. R., 1970, Magnetic anomalies in the Northeast Atlantic between the Canary and Cape verde Islands: Journal of Geophysical Research, v. 75, p. 7412-7420.

Roussel, J., and Liger, J. L., 1983, A review of deep structure and ocean-continent transition in the Senegal basin (West Africa): Tectonophysics, v. 91, p. 183-211. 
Sahabi, M., Aslanian, D., and Olivet, J. L., 2004, A new starting point for the history of the central Atlantic: Comptes Rendus Geoscience, v. 336, p. 1041-1052.

Sandwell, D. T., and Smith, W. H. F., 1997, Marine gravity anomaly from Geosat and ERS1 satellite altimetry: Journal of Geophysical Research Solid Earth, v. 102, p. 10039-10054

Schettino, A., and Turco, E., 2009, Breakup of Pangaea and plate kinematics of the central Atlantic and Atlas regions: Geophysical Journal International, v. 178, p. 1078-1097.

Sheridan, R. E., Gradstein, F. M., Barnard, L. A, Bliefnick, D. M., Habib, D., Jenden, P. D., Kagami, H., Keenan, E. M., Kostecki, J., Kvenvolden, K. A., Moullade, M., Ogg, J., Robertson, A. H. F., Roth, P. H., Shipley, T. H., Wells, H., Bowdler, J. L., Cotillon, P. H., Halley, R. B., Kinoshita, H., Patton, J. W., Pisciotto, K. A., Premoli, S. I., Testarmata, M. M., Tyson, R. V., and Watkins, D. K., 1982, Early history of the Atlantic Ocean and gaz hydrate on the Blake Outer Ridge ; results of the Deep Sea Drilling Project Leg 76: Geological Society of America Bulletin, v. 93, p. 876-885.

Sibuet, J.-C., Monti, S., Loubrieu, B., Maze, J.-P., and Srivastava, S., 2004, Carte bathymetrique de l'Atlantique nord-est et du golfe de Gascogne; implications cinematiques: Bulletin de la Societe Geologique de France, v. 175, p. 429-442.

Sichler, B., Olivet, J. L., Auzende, J. M., Jonquet, H., Bonnin, J., and Bonifay, A., 1980, Mobility of Morocco: Canadian Journal of Earth Sciences = Revue Canadienne des Sciences de la Terre, v. 17, p. 1546-1558.

Small, C., and Sandwell, D. T., 1989, An Abrupt Change in Ridge Axis Gravity With Spreading Rate: Journal of Geophysical Research, v. 94, p. 17383-17392.

Srivastava, S. P., Sibuet, J.-C., Cande, S., Roest, W., and Reid, I. D., 2000, Magnetic evidence for slow seafloor spreading during the formation of the Newfoundland and Iberian margins: Earth and Planetary Science Letters, v. 182, p. 61-76.

Sundvik, M., Larson, R. L., and Detrick, R. S., 1984, The rough-smooth basement boundary in the western North Atlantic Basin; evidence for a seafloor spreading origin: Eos, Transactions, American Geophysical Union, v. 64, p. 321-321.

Talwani, M., Ewing, J., Sheridan, R. E., Holbrook, W. S., and Glover, L., 1995, The edge expriment and the U.S. East Coast Magnetic Anomaly, in Banda, E., and al., eds., Rifted Ocean-Continent Boundaries: Netherlands, Kluwer Academic, p. 155-181.

Taylor, P. T., Zietz, I., and Dennis, L. S., 1968, Geologic implications of aeromagnetic data for the eastern continental margin of the United States: Geophysics, v. 33, p. 755-780.

Torsvik, T. H., Rousse, S., Labails, C., and Smethurst, M., 2009, A new scheme for the opening of the South Atlantic Ocean and the dissection of an Aptian salt basin: Geophysical Journal International, v. 177, p. 1315-1333.

Tucholke, B. E., and Ludwig, W. J., 1982, Strucrure and origin of the J anomaly ridge, western North Atlantic Ocean: Journal of Geophysical Research, v. 87, p. 9389-9407.

Uchupi, E., Emery, K. O., Bowin, C. O., and Phillips, J. D., 1976, Continental margin off Western Africa : Senegal to Portugal: American Association of Petroleum Geologists, v. 60, p. 809-878.

Van der Linden, W. J. M., 1981, The crustal structure and evolution of the continental margin off Senegal and the Gambia, from total-intensity magnetic anomalies: Geologie en Mijnbouw, v. 60, p. 257-266.

Verhoef, J., Roest, W. R., Macnab, R., Arkani-Hamed, J., and Members of the Project Team, 1996, Magnetic anomalies of the Arctic and North Atlantic Oceans and Adjacent land areas, GSC Open file 3125, Geological Survey of Canada, p. 225.

Vogt, P. R., 1973, Early events in the opening of the North Atlantic, in Tarling, D. H., and Runcorn, S. K., eds., Implications of continental drift to the Earth Sciences, 2, Academic Press, p. 693-712.

Vogt, P. R., Anderson, C. N., Bracey, D. R., and Schneider, E. D., 1970, North Atlantic Magnetic Smooth Zones: Journal of Geophysical Research, v. 75, p. 3955-3968.

Wade, J. A., and MacLean, B. C., 1990, Aspects of the geology of the Scotian Basin from recent seismic and well data ; the geology of the southeastern margin of Canada, in Keen, M. J., and Williams, G. L., eds., Geology of the continental margin of Eastern Canada, 2. The Geology of North America, Geological Society of America, p. 190-238.

Welsink, H. J., Dwyer, J. D., and Knight, R. J., 1989, Tectono-stratigraphy of the passive margin off Nova Scotia, in Tankard, A. J., and Balkwill, H. R., eds., Amer. Ass. Petrol. Geol. Bull., 46, p. 215-231.

Wernicke, B., and Tilke, P. G., 1989, Extensional tectonics framework of the U.S. central Atlantic passive margin: AAPG Memoir, v. 46, p. 721.

Wessel, P., and Smith, W. H. F., 2004, The Generic Mapping Tools : GMT (version 4), NOAA/NESDIS/NODC.

Whittaker, J. M., Müller, R. D., Leitchenkov, G., Stagg, H., Sdrolias, M., Gaina, C., and Goncharov, A., 2008, Major Australian-Antarctic Plate reorganization at Hawaiian-Emperor bend time; reply: Science, v. 321, p. 490-490.

Winterer, E. L., and Hinz, K., 1984, The evolution of the Mazagan continental margin : a synthesis of geophysical and geological data with results of drilling during deep sea drilling project leg 79, in Hinz, K., and Winterer, E. L., eds., Initial Reports DSDP, 79: Washington, U. S. Govt. Printing Office, p. 893 - 919.

Wissmann, G., and Roeser, H. A., 1982, A magnetic and halokinetic structural Pangaea fit of Northwest Africa and North America: Geologisches Jahrbuch, v. E, p. 43-61. 
Withjack, M. O., Schlische, R. W., and Olsen, P. E., 1998, Diachronous rifting, drifting, and inversion on the passive margin of central eastern North America; an analog for other passive margins: AAPG Bulletin, v. 82, p. 817-835.

730

731

732 


\section{Figure Captions}

Figure 1: Generalized boundaries of seafloor spreading provinces on both sides of the Central Atlantic Ocean, superimposed on satellite derived gravity (Sandwell and Smith, 1997). Major magnetic anomalies (red) are indicated: ECMA - East Coast; WACMA - West African Coast; BSMA - Blake Spur; ABSMA African Blake Spur; M25 and M0. ECMA and WACMA outlines come from Sahabi et al. (2004), and the M0 anomaly in the North Atlantic from Klitgord and Schouten (1986). The ECMA is represented in two colors (red and orange) depending on its amplitude. Oceanic fracture zones (black) are shown, as well as major tectonic features. Magnetic anomaly provinces are the Jurassic Magnetic Quiet Zone (JMQZ) between the coastal magnetic anomalies (ECMA/WACMA) and Chron M25, and the Mesozoic Magnetic Anomaly Zone seaward of the JMQZ (Chrons M25 to Chrons M0). Abbreviations: MAR, Mid-Atlantic Ridge; GB, Grand Banks of Newfoundland; CAMP, Central Atlantic Magmatic Province; BP, Blake Plateau; DP, Demerara Plateau; GP, Guinean Plateau.

Figure 2: Magnetic anomalies and tectonic interpretation for the eastern Central Atlantic Ocean. (a) The geological survey of Canada (GSC) magnetic grid (Verhoef et al., 1996) is complemented by a new grid off western Africa (this study). (b) Interpreted magnetic isochrons (red), oceanic fracture zones (black) and significant tectonic features (see inset for detailed legend). The observed magnetic anomalies (orange) along selected profiles are projected in a $010^{\circ}$ direction to emphasize the seafloor spreading anomalies. Lines selected for Chron identification are indicated by thick black lines (A-O). TTZF: Tizi n'Test Fault Zone.

Figure 3: Magnetic anomaly data and tectonic interpretation for the western Central Atlantic Ocean. (a) The Geological Survey of Canada (GSC) magnetic grid (Verhoef et al., 1996) is complemented with GEODAS magnetic ship track data (grey) in the southwestern Central Atlantic. (b) Interpreted magnetic isochrons (red), oceanic fracture zones (black) and significant tectonic features (see inset for detailed legend). The observed magnetic anomalies (orange) along selected profiles are projected in a $010^{\circ}$ direction to emphasize the seafloor spreading anomalies. Ship tracks selected for Chron identification are indicated by thick black lines (A-O). The Black triangle (south of $30^{\circ} \mathrm{N}$ ) shows the position of DSDP 534 core that provides by extrapolation the age of the BSMA at c. 170 Ma, (early Bajocian).

Figure 4: Magnetic anomaly profiles showing the interpretation of the African conjugate of the Blake Spur Anomaly, the ABSMA. Location of profiles is indicated on the upper-left figure which corresponds to the reconstruction at Chron M25. Note the symmetry in shape and position with respect to the ECMA and the margins. Abbreviations: ECMA, East Coast Magnetic Anomaly; WACMA, West African Coast Magnetic Anomaly; BSMA, Blake Spur Magnetic Anomaly; ABSMA, African Blake Spur Magnetic Anomaly; IMQZ, Inner Magnetic Quiet Zone. 
Figure 5: Magnetic anomaly profiles showing the interpretation of the M-series magnetic anomalies (M0 to M25); the left panel shows the western Atlantic and the right panel the eastern Atlantic Ocean. Chrons M0, M10n, M16, M21, M22 and M25 are identified by comparison with synthetic profiles (bottom) created by two-dimensional models based on the geomagnetic timescale of Gradstein et al. (2004), using paleopole parameters for the remanent magnetic field (Besse and Courtillot, 2003), a depth to the top of the magnetized layer of $8 \mathrm{~km}$, and spreading rates of our kinematic model. Line locations are displayed in figures 2a and 3a.

Figure 6: Opening of the Central Atlantic Ocean as proposed in this study, starting from the continental fit (190 Ma), and showing reconstructions at Blake Spur time, Chron M25, Chron M22 and Chron M0 (170, 154, 150 and 125 Ma respectively). North America is fixed. The SFS data on the American side (blue) and on the African side (red) are displayed, as well as important tectonic features that are discussed in the text. Positions of South America respect to Africa comes from Torsvik et al. (2009)

Figure 7: Simplified Trias to Cretaceous chronology of seafloor spreading, magmatic events, major sedimentary formations of the Central Atlantic and full spreading rates calculated for two geographic locations in Morocco and in Northwest Africa. Timescale after Gradstein et al. (2004), sedimentary events summarized from Jansa and Wiedmann (1982) and Wade and MacLean (1990), magmatic events from Nomade et al. (2007).

Figure 8: Comparison of half-spreading rates between our model and previous works (Klitgord and Schouten, 1986; Bird et al., 2007; Schettion and Turco, 2009). Ridge jumps are indicated by vertical arrows. Abbreviation: RD, Ridge jumps assumed to occur on the American side.

Figure 9: Sketch map of the circum-Atlantic Ocean volcanic activity (purple) and Triassic-Early Jurassic rifted basins (green) at c. 203 Ma (location after Choubert et al., 1968; Marzoli et al., 1999; Davidson, 2005). The relative reconstruction poles with respect to a fixed North American Plate are as follows: Moroccan Meseta Plate, $66.23^{\circ},-11.28^{\circ},-73.91^{\circ}$; Northwest Africa Plate, $64.28^{\circ},-14.74^{\circ},-78.05^{\circ}$. Abbreviation: GB, Grand Banks.

Figure 10: Reconstruction at M0 (125 Ma), in the reference frame of the stage pole from M0 to BSMA. In this representation, oceanic fracture zones (blue/black) are oriented east-west, and the asymmetric spreading history is highlighted (see text for discussion). See legend of Figure 2a for details. The grey shaded area in the centre of CAO corresponds to the asymmetric spreading rate domain.

Table 1: Relative reconstruction parameters (finite poles) with respect to a fixed North American Plate. 


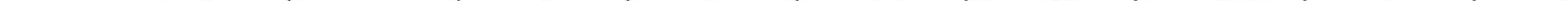




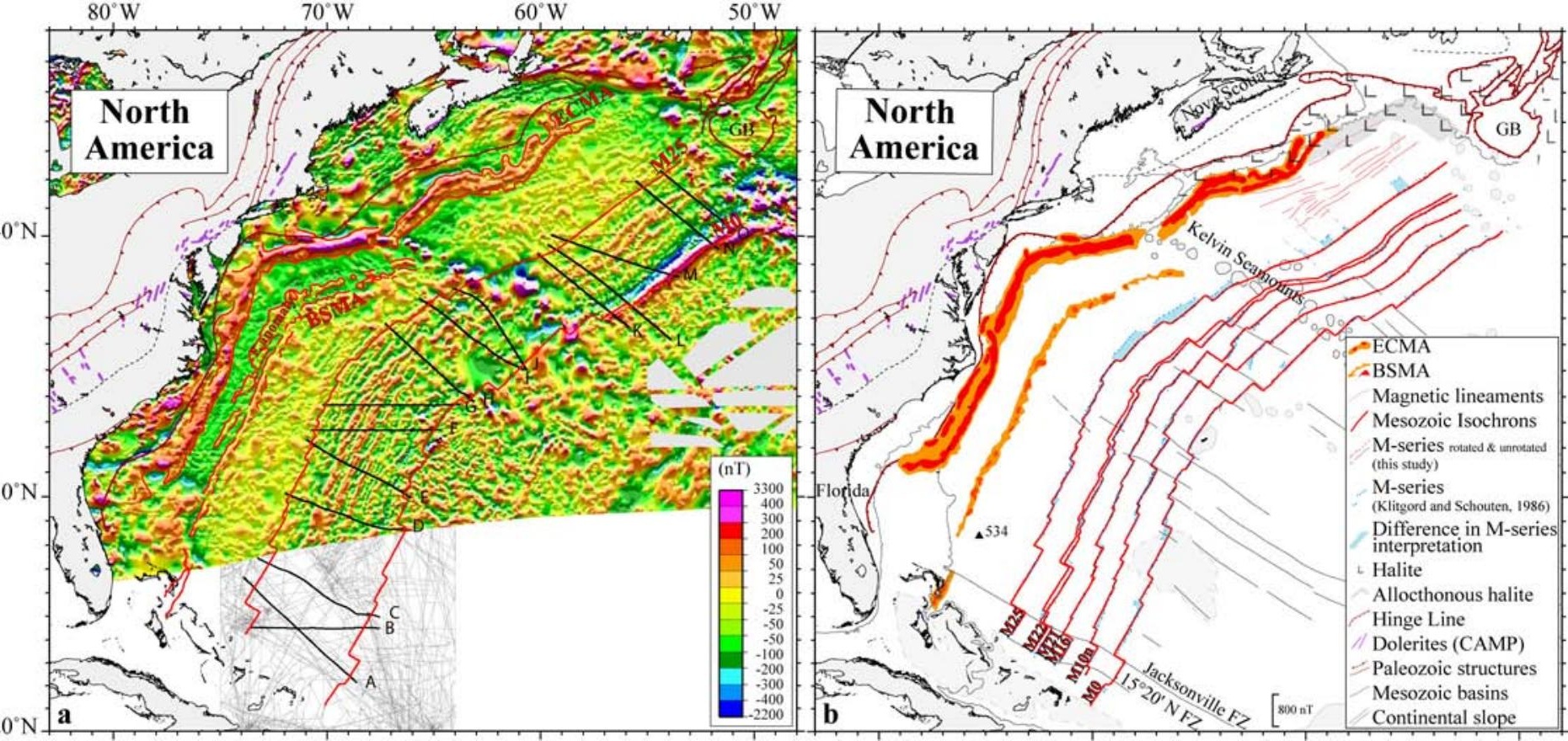




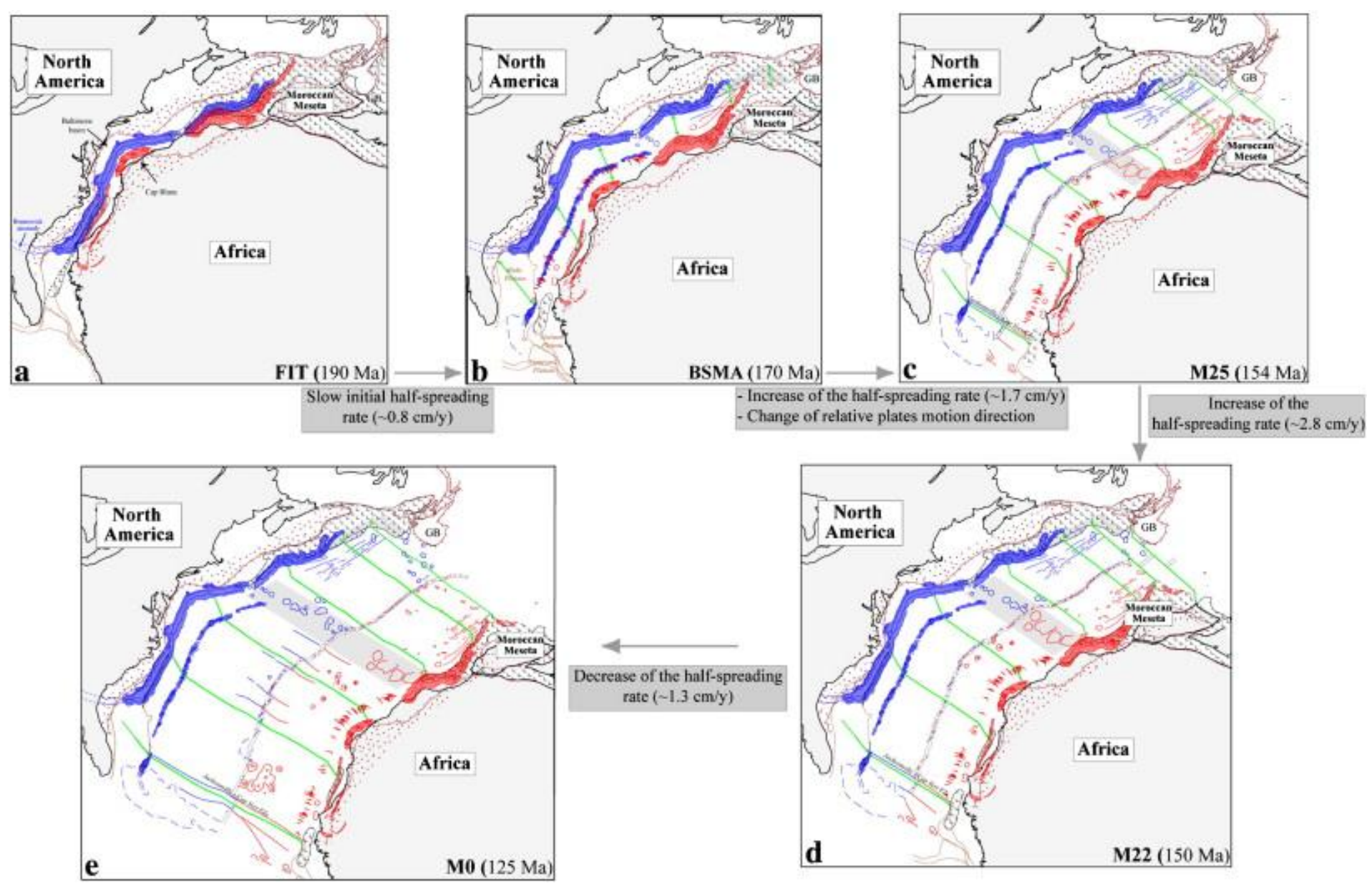


Chrono-stratigraphic time scale

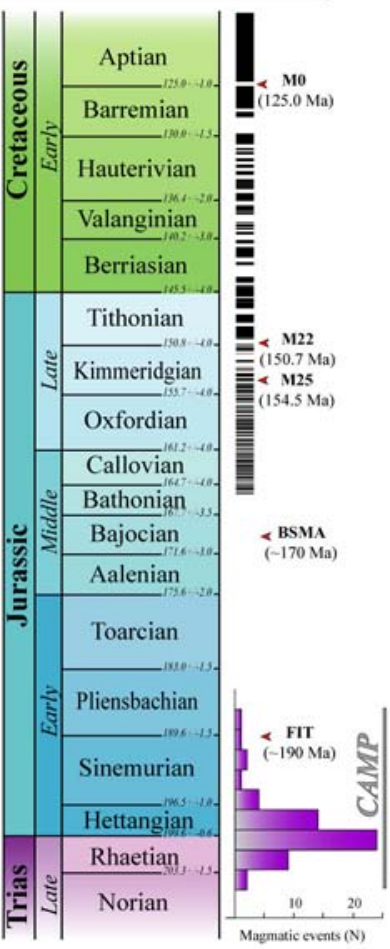

Tectonic evolution

(Scotian vs. Moroccan basins)

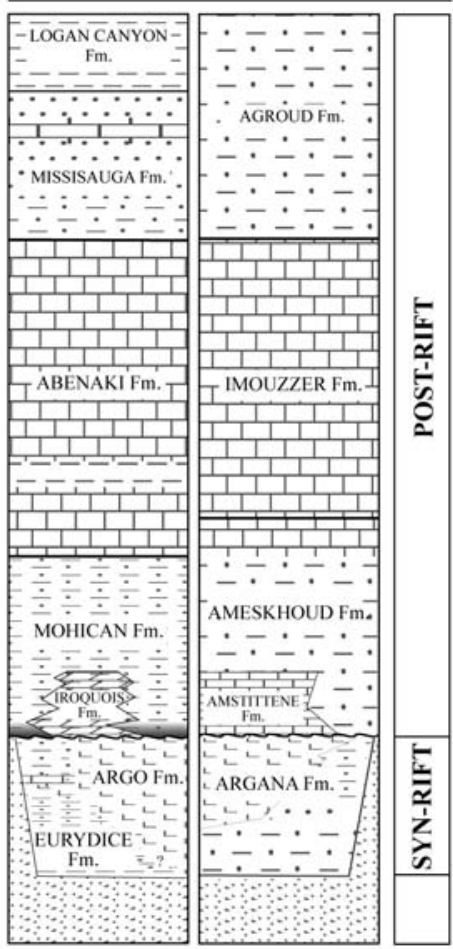

Relative full spreading rates

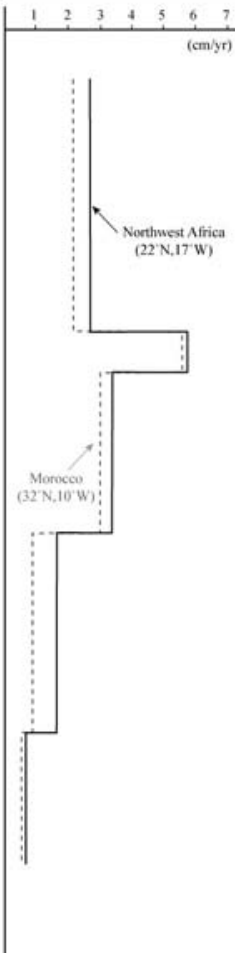




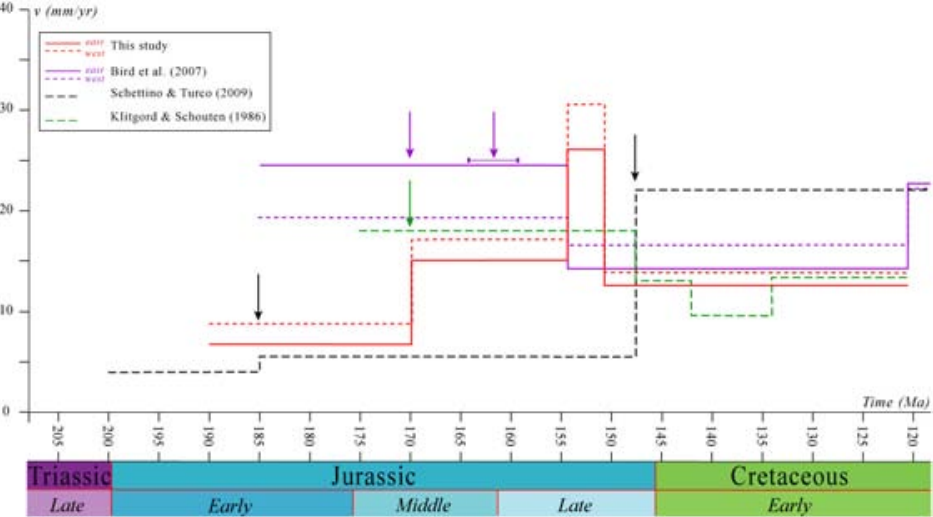




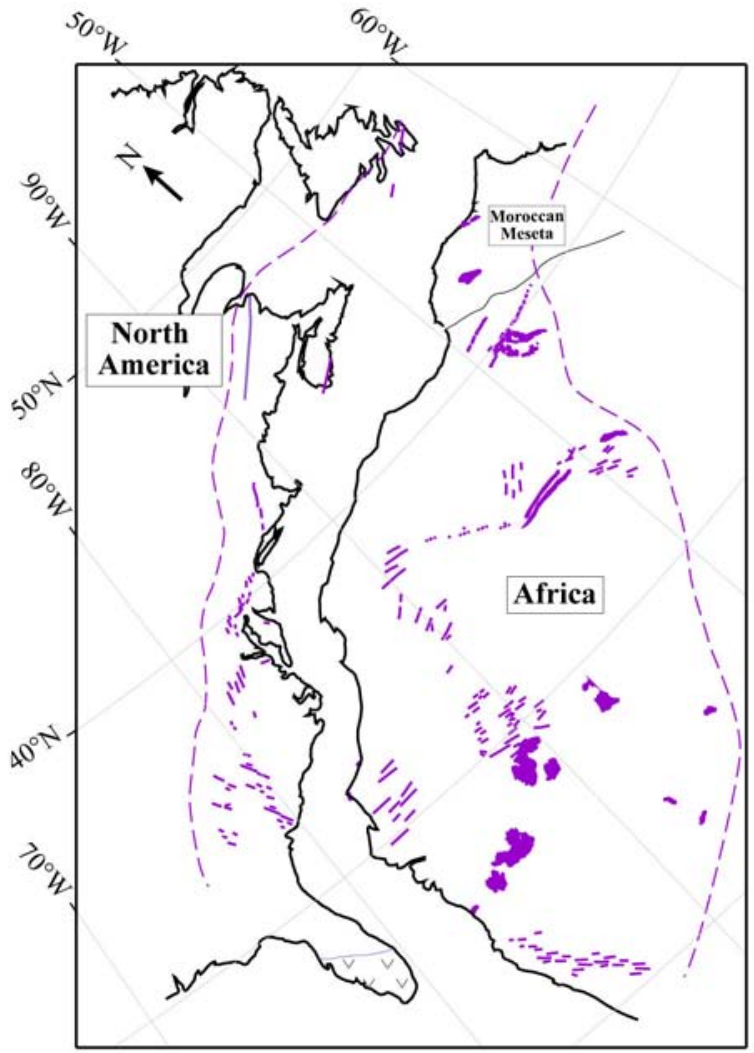




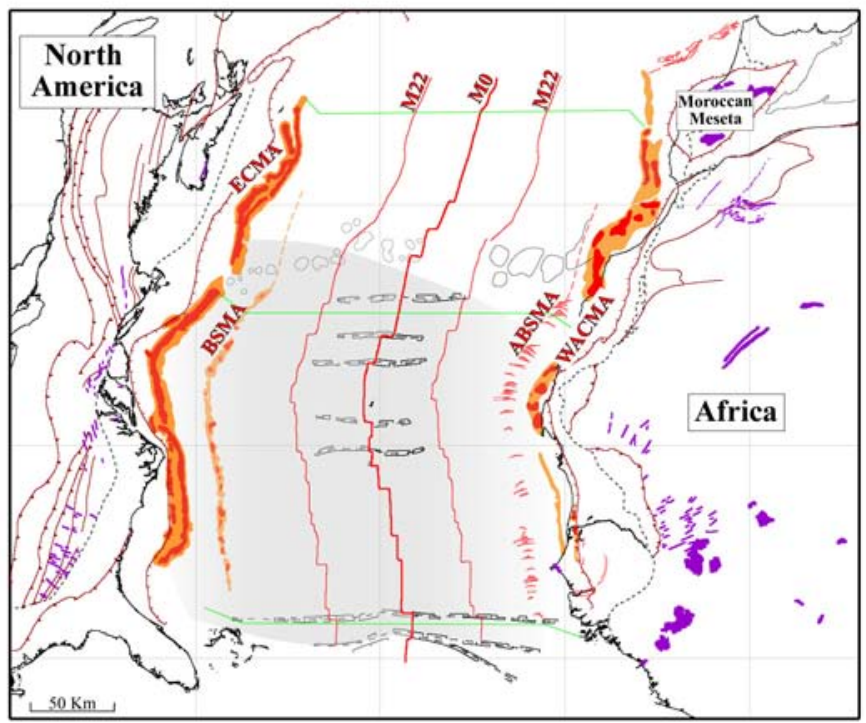




\begin{tabular}{|c|c|c|c|c|c|c|c|c|}
\hline \multirow{3}{*}{$\begin{array}{l}\text { Magnetic } \\
\text { lineation }\end{array}$} & \multirow{3}{*}{$\begin{array}{l}\text { Age } \\
(\mathrm{Myr})^{*}\end{array}$} & \multicolumn{3}{|c|}{ Northwest African Plate } & \multicolumn{3}{|c|}{ Moroccan Meseta Plate } & \multirow[t]{3}{*}{ References } \\
\hline & & Latitude & Longitude & Angle & Latitude & Longitude & Angle & \\
\hline & & $\left({ }^{\circ}\right)$ & $\left({ }^{\circ}\right)$ & $\left({ }^{\circ}\right)$ & $\left({ }^{\circ}\right)$ & $\left({ }^{\circ}\right)$ & $\left({ }^{\circ}\right)$ & \\
\hline \multirow[t]{3}{*}{ Closure (max) } & 203 & 64.28 & -14.74 & -78.05 & 66.23 & -11.28 & -73.91 & 1 \\
\hline & 230 & 68.59 & -5.76 & -71.36 & -68.35 & -9.57 & -73.19 & 5 \\
\hline & 175 & 66.95 & -12.02 & -75.55 & 66.95 & -12.02 & -75.55 & 3 \\
\hline \multirow[t]{4}{*}{ Closure (min.) } & 190 & 64.31 & -15.19 & -77.09 & 66.31 & -11.78 & -72.95 & 2 \\
\hline & 200 & 68.28 & -10.00 & -70.06 & -68.35 & -9.57 & -73.19 & 5 \\
\hline & 185 & 68.01 & -12.80 & -69.22 & -67.98 & -13.09 & -72.09 & 5 \\
\hline & 175 & 66.97 & -12.34 & -74.57 & 66.97 & -12.34 & -74.57 & 3 \\
\hline \multirow[t]{2}{*}{ BSMA } & \multirow[t]{2}{*}{170} & 67.09 & -13.86 & -70.55 & 69.47 & -09.56 & -66.59 & 1 \\
\hline & & 67.02 & -13.17 & -72.10 & 67.02 & -13.17 & -72.10 & 3 \\
\hline \multirow[t]{3}{*}{ Anomaly M25 } & \multirow[t]{3}{*}{154} & 67.10 & -15.86 & -64.23 & 68.52 & -13.69 & -61.75 & 1 \\
\hline & & 67.15 & -16.00 & -64.70 & 67.15 & -16.00 & -64.70 & 3 \\
\hline & & 66.10 & -16.45 & -65.84 & 66.10 & -16.45 & -65.84 & 4 \\
\hline Anomaly M22 & 150 & 66.08 & -18.44 & -62.80 & 66.61 & -17.66 & -61.83 & 1 \\
\hline \multirow[t]{3}{*}{ Anomaly M0 } & \multirow[t]{3}{*}{125} & 65.95 & -20.46 & -54.56 & 67.17 & -19.51 & -53.01 & 1 \\
\hline & & 66.30 & -19.90 & -54.25 & 66.30 & -19.90 & -54.25 & 3 \\
\hline & & 66.70 & -18.55 & -54.23 & 66.70 & -18.55 & -54.23 & 4 \\
\hline
\end{tabular}

${ }^{*}$ Gradstein et al. (2004).(1) This study, (2) Sahabi et al. (2004), (3) Klitgord and Schouten (1986), (4) Bird et al. (2007), (5) Schettino \& Turco (2009). 


\section{Appendix A. Magnetic Map of the West African margin}

This section describes a compilation of magnetic data collected during the period 1961-2002 off West Africa (south of the Canary Islands). In order to have clean magnetic data that can be used to reconstruct the West African margin with its eastern Atlantic counterpart, we have compiled all available data off West Africa, between $10^{\circ} \mathrm{N}$ and $30^{\circ} \mathrm{N}$ located on the African plate.

The magnetic data-set consist of numerous measurements through the area from detailed surveys (Van der Linden, 1981 and Roeser et al., 2002), together with data from Ifremer and GEODAS, and available in a variety of forms and with significantly different accuracies. All data were in digital form as profile data, representing original observations along ship tracks. The track chart of magnetic data (Figure A1) shows the coverage of the area. A total of 124 different ship surveys were combined, representing more than 120000 line km of ship tracks and about 208000 total intensity magnetic observations. The navigation accuracy of the ship surveys is quite variable, with the older surveys using celestial and/or transit satellite navigation (with an accuracy of 5 to $10 \mathrm{~km}$ at best), while the more recent surveys had GPS (Global Positionning System) navigation available (with an accuracy of better than $1 \mathrm{~km}$ ). This means that the data quality is highly variable with the older data more likely to be the most inaccurate. To process such a heterogeneous data-set, and to construct a coherent gridded data-set, we employed several data handling procedures. Some of the most pertinent cleaning and correction methods used are outlined in the next sections.

\section{A.1 Initial editing of the data}

The data were collected over a period of 41 years, and so the secular variation of the earth's magnetic field has to be accounted for. These variations are modeled in a series of mathematical fields (International Geomagnetic Reference Field IGRF10) defined for successive 5-years epochs, which were used to reduce all observations to anomalies.

After reduction to anomalies, all the data were displayed and visually checked for obvious erroneous data points (such as spikes, the most commonly found errors), which were deleted. During the visual inspection of the data-set, several cruises were identified for which the profile data were of questionable quality due to either very irregular sampling or very noisy data. Most of these data were eliminated from the database; however, because many of these cruises were located in regions with no adequate alternative data, we endeavored to keep as many data points as possible. About $9 \%$ of data points were finally deleted. The next step in the processing of the data consisted of a cross-over analysis to investigate the internal consistency of the data-set and to locate leveling problems. 
829 Levels of the cruise data-sets were adjusted by minimizing the variety of errors at crossover points. A 830 cross-over is a point of intersection between two segments of ship tracks. These errors can be related to short-term temporal variations of the geomagnetic field, or other errors that may lead to background value difference. The procedure has been carried out using the method of Mauring and Kihle (2006), which is based on filtering line data. For a given line, a 1D median was determined at each data point based on data values within a given distance from that point. In a similar way, a 2D median value is determined from the nearby data values in the current line, and inside the circle that intersects neighboring lines. The difference between the 2D and 1D median value is taken as the leveling error and the level correction is performed by adding this value to the data value at the current station. Figure A2 shows the gridded dataset before adjustment and clearly shows significant cross-over errors and level problems on some ship tracks.

First, a $100 \mathrm{~km}$ Butterworth high-pass filter was applied to the grid to remove trends in the differential median leveling. This wavelength is equivalent to about four times the average line spacing. Here, the 1D filter length is $150 \mathrm{~km}$ and the 2D filter radius is $250 \mathrm{~km}$ (about 3.5 times the maximum line spacing). Radii of 150, 200, 300, $500 \mathrm{~km}$ were used while keeping the 1D filter length constant. The absolute average differences between the correction values were $0.7 \mathrm{nT}, 0.5 \mathrm{nT},<0.01 \mathrm{nT}$, and $0.9 \mathrm{nT}$ respectively for all ship tracks. Using a filter radius larger than $250 \mathrm{~km}$ had little effect on the quality of the final leveled result. The setting of the 1-D parameter is a matter of trial and error; as a rule of thumb, twice the length of the shortest line error wavelength is used. The 2-D parameter should be set so that it intersects at least 2.5 neighboring lines at the maximum line spacing. The correction values should be smoothed prior to adding them to the pre-processed data; here a non-linear filter, suitable for removing high amplitude and short wavelength noise, was applied with a width of 5 data points and an amplitude tolerance of 0.001 nT. The effect of the adjustment can be seen in the plot of the gridded data-set (Figure A3). A comparison of the two grid images (Figures 3 and 4) shows the extent of the line-level errors in the original data. This is best seen in the corresponding high-pass filtered grid image of Figure A4 (100 km Butterworth high-pass filter). The processing corrects most of the level errors; some line-level errors remain, and are especially obvious in the southern part of the grid.

856

\section{A.3 Final merge}

The final step consisted in merging the magnetic grid obtained from the cleaned and adjusted data-set with the marine compilation of Verhoef et al. (1996) (Figure A5), using the Oasis montaj GridKnit module GRIDSTCH GX. This module is used to stitch two geophysical grids with different cell size, projection or grid type into a single grid via standard smoothing functions. We used the suture grid- 
861

862

863

864

865

866

867

868

869

870

871

872

873

874

875

876

877

878

879

880

881

stitching methods. This method defines a line at which to join the two grids. The line, of necessity, lies completely within the overlapping area of the two grids. The "cut-off" sections of the grid do not contribute to the final grid. Along the suture line the mismatch in the grid values must be corrected by adjusting the grids on either side of the path. The first grid acts as the "master grid". Its projection and cell size determine the projection and cell size used in the output grid, unless a different cell size is specified. The second grid does not need to share the same projection or cell size as the first grid. Point values are automatically interpolated and transformed to the output grid with projection type inherited from the first grid, and using a specified or default cell size.

\section{Figure captions}

Figure A1: Track chart of data used for the final grid compiled in this study.

Figure A2: Gridded data-set before adjustment clearly showing significant cross-over errors and level problems on some ship tracks.

Figure A3: Grid of differential median leveled data with a 1D filter length of $150 \mathrm{~km}$ and a 2D filter radius of $250 \mathrm{~km}$. The level correction values are smoothed using a non-linear filter with a width of 5 data points and $0.001 \mathrm{nT}$ tolerance value.

Figure A4: Residual grid differential median leveled data after applying a 100-km Butterworth high-pass filter to the preprocessed data.

Figure A5: Final compilation after merging the magnetic grid obtained from the cleaned and adjusted data-set with the marine compilation of Verhoef et al. (1996). 

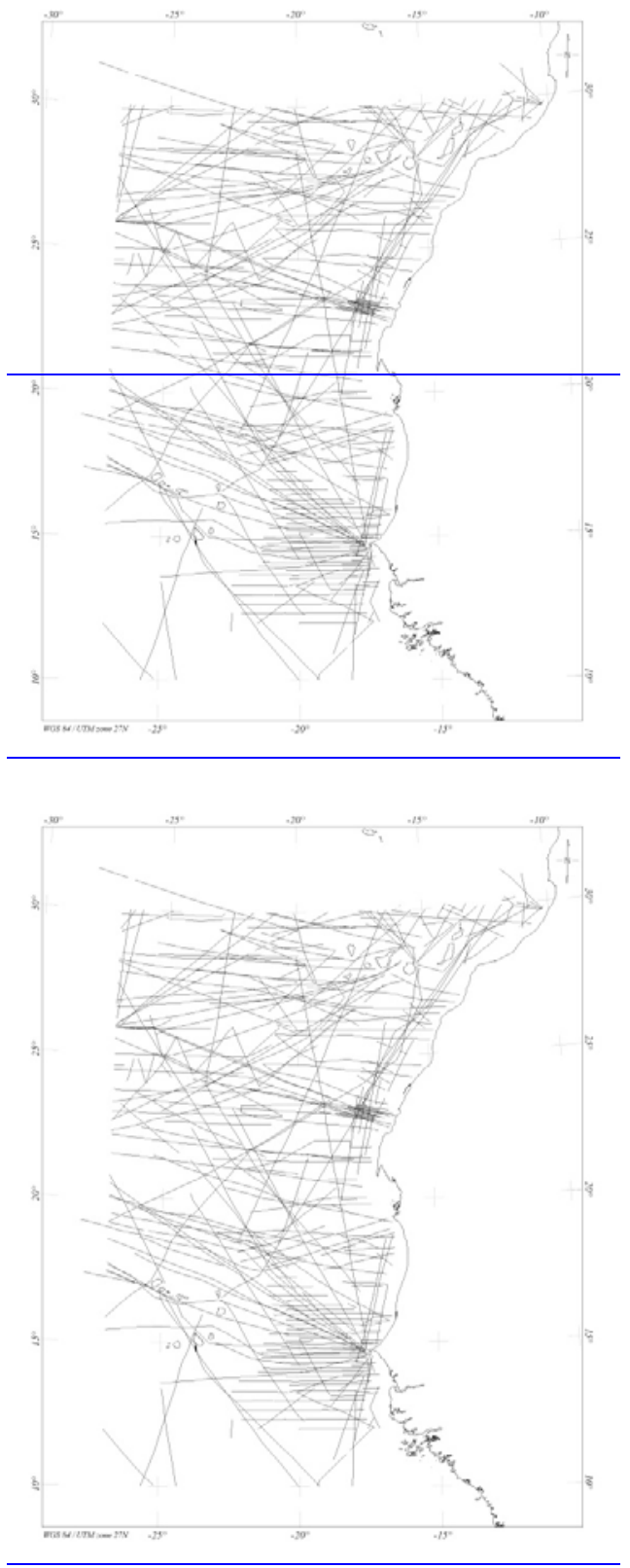
886

887
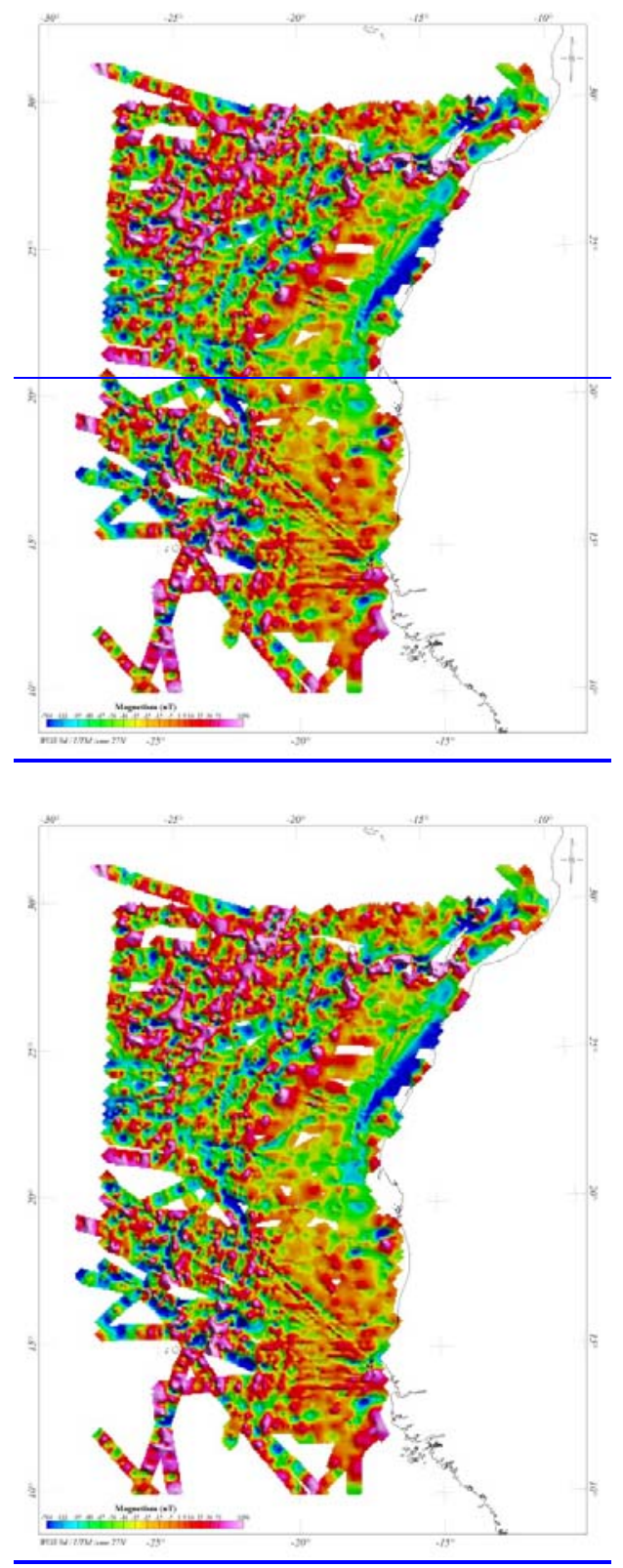

Figure A2

890 
890

891

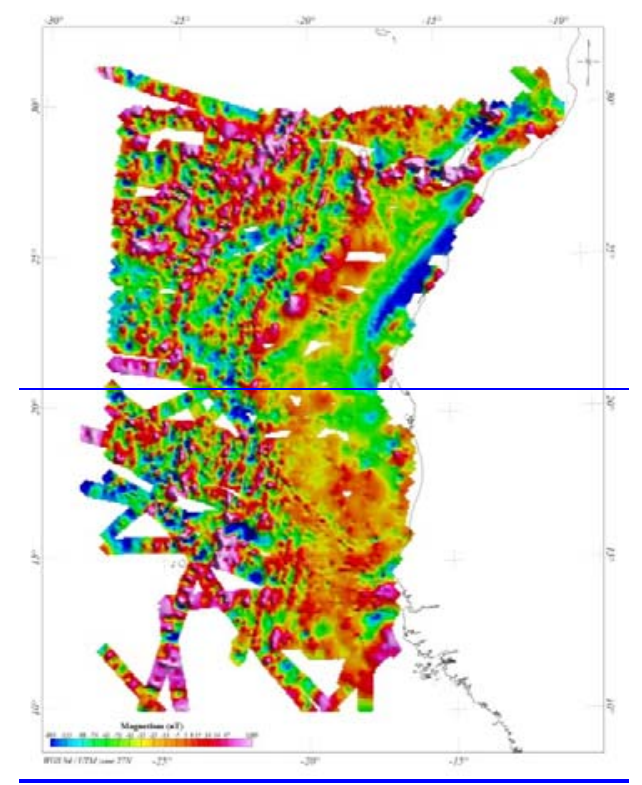

892

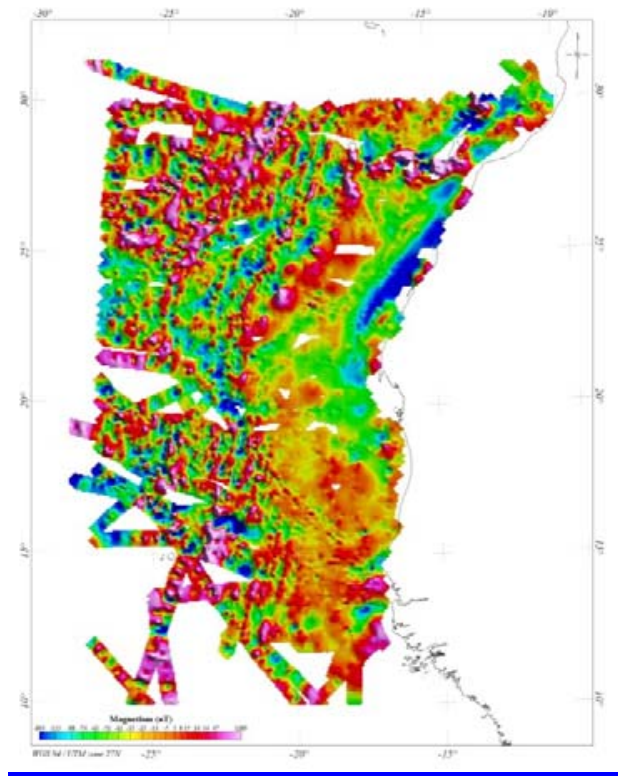

893

Figure A3

894 

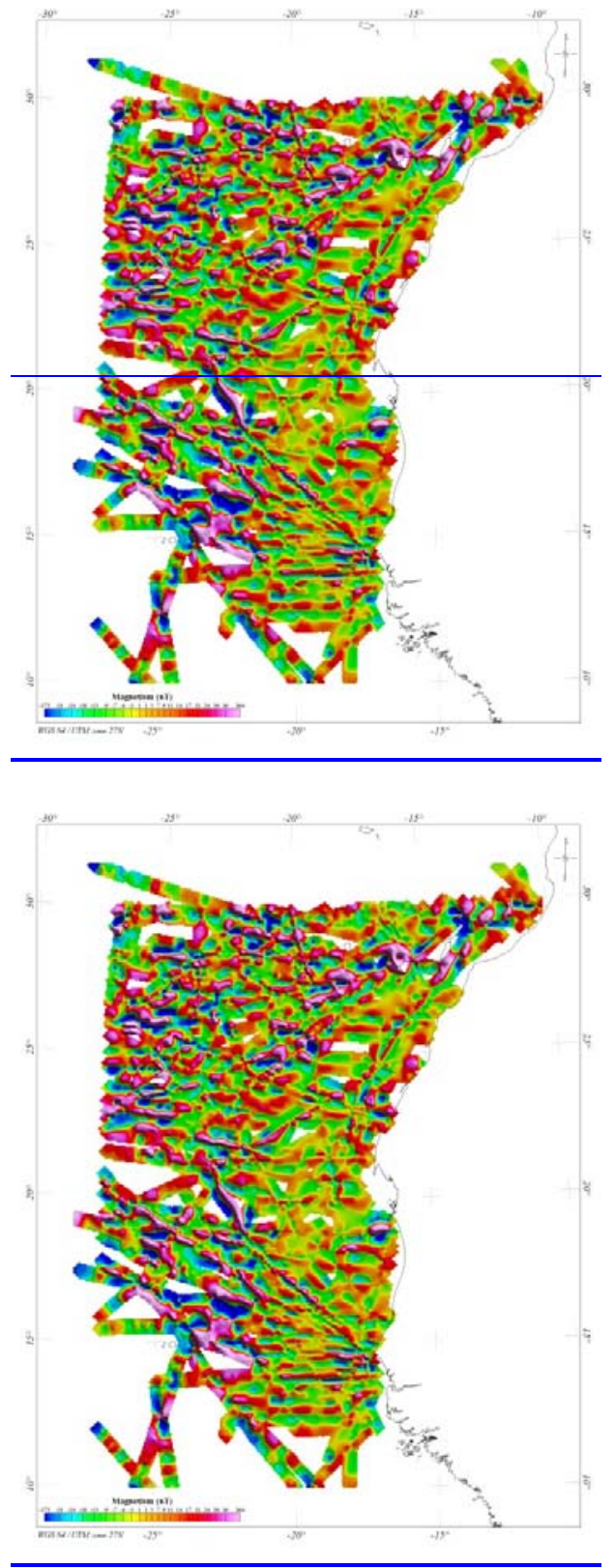
898

899
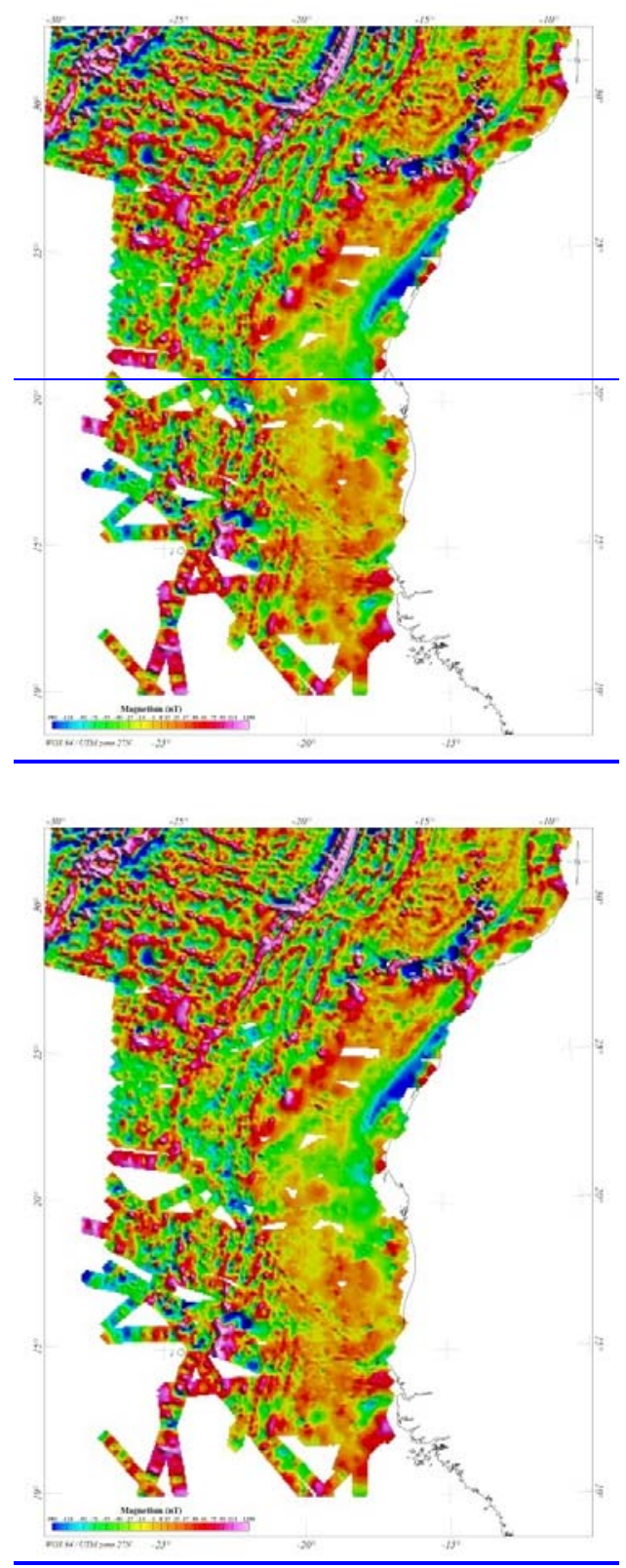

Figure A5

902

903

904

905 